NBER WORKING PAPER SERIES

\title{
THE EFFECT OF PROVIDING PEER INFORMATION ON RETIREMENT SAVINGS DECISIONS
}

\author{
John Beshears \\ James J. Choi \\ David Laibson \\ Brigitte C. Madrian \\ Katherine L. Milkman \\ Working Paper 17345 \\ http://www.nber.org/papers/w17345
}

\author{
NATIONAL BUREAU OF ECONOMIC RESEARCH \\ 1050 Massachusetts Avenue \\ Cambridge, MA 02138 \\ August 2011
}

We thank Aon Hewitt and our corporate partner for conducting the field experiment and providing the data. We are particularly grateful to Pam Hess, Mary Ann Armatys, Diane Dove, Barb Hogg, Diana Jacobson, Larry King, Bill Lawless, Shane Nickerson, and Yan Xu, some of our many contacts at Aon Hewitt. We thank Sherry Li and seminar participants at Berkeley, Cornell, Stanford, Wharton, the NBER Summer Institute, the Harvard Business School / Federal Reserve Bank of Boston Consumer Finance Workshop, and the Behavioral Decision Research in Management Conference for their insightful feedback. Michael Buckley, Yeguang Chi, Christina Jenq, John Klopfer, Henning Krohnstad, and Eric Zwick provided excellent research assistance. Beshears acknowledges financial support from a National Science Foundation Graduate Research Fellowship. Beshears, Choi, Laibson, and Madrian acknowledge individual and collective financial support from the National Institute on Aging (grants R01-AG-021650, P01-AG-005842, and T32-AG-000186). This research was also supported by the U.S. Social Security Administration through grant \#19-F-10002-9-01 to RAND as part of the SSA Financial Literacy Research Consortium. The findings and conclusions expressed are solely those of the authors and do not represent the views of SSA, any agency of the Federal Government, RAND, or the National Bureau of Economic Research. See the authors' websites for lists of their outside activities.

NBER working papers are circulated for discussion and comment purposes. They have not been peerreviewed or been subject to the review by the NBER Board of Directors that accompanies official NBER publications.

(C) 2011 by John Beshears, James J. Choi, David Laibson, Brigitte C. Madrian, and Katherine L. Milkman. All rights reserved. Short sections of text, not to exceed two paragraphs, may be quoted without explicit permission provided that full credit, including $\mathbb{C}$ notice, is given to the source. 
The Effect of Providing Peer Information on Retirement Savings Decisions

John Beshears, James J. Choi, David Laibson, Brigitte C. Madrian, and Katherine L. Milkman

NBER Working Paper No. 17345

August 2011, Revised August 2014

JEL No. D03,D14,D83,D91

\section{ABSTRACT}

We conducted a field experiment in a 401(k) plan to measure the effect of disseminating information about peer behavior on savings. Low-saving employees received simplified plan enrollment or contribution increase forms. A randomized subset of forms stated the fraction of age-matched coworkers participating in the plan or age-matched participants contributing at least $6 \%$ of pay to the plan. We document an oppositional reaction: the presence of peer information decreased the savings of non-participants who were ineligible for 401(k) automatic enrollment, and higher observed peer savings rates also decreased savings. Discouragement from upward social comparisons seems to drive this reaction.

John Beshears

Harvard Business School

Baker Library 439

Soldiers Field

Boston, MA 02163

and NBER

jbeshears@hbs.edu

James J. Choi

Yale School of Management

135 Prospect Street

P.O. Box 208200

New Haven, CT 06520-8200

and NBER

james.choi@yale.edu

David Laibson

Department of Economics

Littauer M-12

Harvard University

Cambridge, MA 02138

and NBER

dlaibson@gmail.com
Brigitte C. Madrian

Harvard Kennedy School

79 JFK Street

Cambridge, MA 02138

and NBER

Brigitte_Madrian@Harvard.edu

Katherine L. Milkman

University of Pennsylvania

3730 Walnut Street

561 Jon M. Huntsman Hall

Philadelphia, PA19104

kmilkman@wharton.upenn.edu

An online appendix is available at:

http://www.nber.org/data-appendix/w17345/ 


\title{
The Effect of Providing Peer Information on Retirement Savings Decisions
}

\author{
JOHN BESHEARS, JAMES J. CHOI, DAVID LAIBSON, BRIGITTE C. MADRIAN, AND \\ KATHERINE L. MILKMAN*
}

July 27,2014

Journal of Finance, forthcoming

\begin{abstract}
We conducted a field experiment in a 401(k) plan to measure the effect of disseminating information about peer behavior on savings. Low-saving employees received simplified plan enrollment or contribution increase forms. A randomized subset of forms stated the fraction of age-matched coworkers participating in the plan or age-matched participants contributing at least $6 \%$ of pay to the plan. We document an oppositional reaction: the presence of peer information decreased the savings of non-participants who were ineligible for 401(k) automatic enrollment, and higher observed peer savings rates also decreased savings. Discouragement from upward social comparisons seems to drive this reaction.
\end{abstract}

\footnotetext{
*Harvard University and NBER, Yale University and NBER, Harvard University and NBER, Harvard University and NBER, and University of Pennsylvania. We thank Aon Hewitt and our corporate partner for conducting the field experiment and providing the data. We are particularly grateful to Pam Hess, Mary Ann Armatys, Diane Dove, Barb Hogg, Diana Jacobson, Larry King, Bill Lawless, Shane Nickerson, and Yan Xu, some of our many contacts at Aon Hewitt. We thank Campbell Harvey (the Editor), an Associate Editor, an anonymous referee, Hunt Allcott, Sherry $\mathrm{Li}$, and seminar participants at Brigham Young University, Case Western Reserve University, Cornell University, New York University, Norwegian School of Economics, Stanford University, University of California Berkeley, University of Maryland, University of Pennsylvania, the NBER Summer Institute, the Harvard Business School / Federal Reserve Bank of Boston Consumer Finance Workshop, and the Behavioral Decision Research in Management Conference for their insightful feedback. Michael Buckley, Yeguang Chi, Christina Jenq, John Klopfer, Henning Krohnstad, Michael Puempel, Alexandra Steiny, and Eric Zwick provided excellent research assistance. Beshears acknowledges financial support from a National Science Foundation Graduate Research Fellowship. Beshears, Choi, Laibson, and Madrian acknowledge individual and collective financial support from the National Institutes of Health (grants P01-AG-005842, R01-AG-021650, and T32-AG-000186). This research was also supported by the U.S. Social Security Administration through grant \#19-F-10002-9-01 to RAND as part of the SSA Financial Literacy Research Consortium. The findings and conclusions expressed are solely those of the authors and do not represent the views of SSA, any agency of the Federal Government, or RAND. See the authors' websites for lists of their outside activities.
} 
In 1980, 30 million U.S. workers actively participated in employer-sponsored defined benefit (DB) retirement savings plans, and 19 million actively participated in employersponsored defined contribution (DC) retirement savings plans. By 2011, participation in DB plans had nearly halved to 17 million workers, while DC plan participation had skyrocketed to 74 million workers. ${ }^{2}$ The shift from DB plans, which set contribution levels and investment allocations on behalf of employees, to DC plans, which allow employees to choose from a complex array of possible contribution levels and investment allocations, has arrived amidst concerns that workers are not equipped to make well-informed savings choices (Mitchell and Lusardi, 2011). Employers have become increasingly interested in programs designed to help employees make good choices in DC plans. This paper studies such a program.

We use a field experiment to investigate the effect of a peer information intervention on retirement savings choices. Peer information interventions involve disseminating information about what a target population's peers typically do. By sharing this information, it may be possible to teach people that a certain behavior is more common than they had previously believed, motivating those people to engage in the behavior more themselves. This approach has been dubbed "social norms marketing" and is used at approximately half of U.S. colleges in an effort to reduce student alcohol consumption (Wechsler et al., 2003).

There are several theoretical reasons why peer information interventions may succeed at moving behavior towards the peer-group average. An individual may mimic peers because their behavior reflects private information relevant to the individual's payoffs (Banerjee, 1992; Bikhchandani, Hirshleifer, and Welch, 1992; Ellison and Fudenberg, 1993). Another possibility is that the intervention provides information about social norms from which deviations are costly due to a taste for conformity, the risk of social sanctions, identity considerations, or strategic complementarities (Asch, 1951; Festinger, 1954; Akerlof, 1980; Bernheim, 1994; Akerlof and Kranton, 2000; Glaeser and Scheinkman, 2003; Benjamin, Choi, and Strickland, 2010; Benjamin, Choi, and Fisher, 2010). Finally, individuals may directly derive utility from relative consumption (Abel, 1990).

A growing empirical literature documents that peer effects indeed play a role in financial decisions when peers interact with each other organically. Peers affect retirement saving

\footnotetext{
${ }^{2}$ Source: U.S. Department of Labor Employee Benefits Security Administration, Private Pension Plan Bulletin Historical Tables and Graphs, Table E8, June 2013.
} 
outcomes (Duflo and Saez, 2002 and 2003), stock market participation (Hong, Kubik, and Stein, 2004; Brown et al., 2008), corporate compensation and merger practices (Bizjak, Lemmon, and Whitby, 2009; Shue, 2013), entrepreneurial risk-taking (Lerner and Malmendier, 2013), and general economic attitudes such as risk aversion (Ahern, Duchin, and Shumway, 2013). ${ }^{3}$ Peer information interventions such as the one we study are designed to harness the power of these peer effects to influence behavior.

Many studies find that peer information interventions cause behavior to more closely conform to the disseminated peer norm. ${ }^{4}$ Our field experiment, however, yields a surprising result. Peer information interventions can generate an oppositional reaction: information about the high savings rates of peers can lead low-saving individuals to shift away from the peer norm and decrease their savings relative to a control group that did not receive peer information. Our evidence suggests that this effect is driven in part by peer information causing some individuals to become discouraged, making them less likely to increase their savings rates.

We conducted our experiment in partnership with a large manufacturing firm and its retirement savings plan administrator. Employees received different letters depending on their 401(k) enrollment status. Employees who had never participated in the firm's 401(k) plan were mailed Quick Enrollment (QE) letters, which allowed them to start contributing 6\% of their pay to the plan with a pre-selected asset allocation by returning a simple reply form. Employees who had previously enrolled but were contributing less than $6 \%$ of their pay received Easy Escalation (EE) letters, which included a nearly identical reply form that could be returned to increase their contribution rate to $6 \%$. Previous work has shown that these simplified enrollment and

\footnotetext{
${ }^{3}$ Hirshleifer and Teoh (2003) review the literature on herding and related phenomena in financial markets. For evidence of peer effects in other domains, see Cialdini, Reno, and Kallgren (1990), Case and Katz (1991), Besley and Case (1994), Hershey et al. (1994), Foster and Rosenzweig (1995), Glaeser, Sacerdote, and Scheinkman (1996), Bertrand, Luttmer, and Mullainathan (2000), Kallgren, Reno, and Cialdini (2000), Sacerdote (2001), Munshi (2004), Munshi and Myaux (2006), Sorensen (2006), Gerber, Green, and Larimer (2008), Grinblatt, Keloharju, and Ikäheimo (2008), Kuhn et al. (2011), Narayanan and Nair (2013), and Chalmers, Johnson, and Reuter (forthcoming). Manski (2000) provides an overview of issues in the social interaction literature.

${ }^{4}$ For example, providing information about peers moves behavior towards the peer norm in domains such as entrée selections in a restaurant, contributions of movie ratings to an online community, small charitable donations, music downloads, towel re-use in hotels, taking petrified wood from a national park, and stated intentions to vote (Cai, Chen, and Fang, 2009; Chen et al., 2010; Frey and Meier, 2004; Salganik, Dodds, and Watts, 2006; Goldstein, Cialdini, and Griskevicius, 2008; Cialdini et al., 2006; Gerber and Rogers, 2009). However, Beshears et al. (2013) find that disseminating short printed testimonials from peers is not effective at increasing conversion from brandname prescription drugs to lower-cost therapeutic equivalents.
} 
contribution escalation mechanisms significantly increase savings plan contributions (Choi, Laibson, and Madrian, 2009; Beshears et al., 2013).

We assigned the QE and EE mailing recipients to one of three randomly selected treatments. The mailing for the first randomly selected treatment included information about the savings behavior of coworkers in the recipient's five-year age bracket (e.g., employees at the firm between the ages of 20 and 24, employees between the ages of 25 and 29, etc.). The mailing for the second randomly selected treatment contained similar information about coworkers in the recipient's ten-year age bracket (e.g., employees at the firm between the ages of 20 and 29). The mailing for the third randomly selected treatment contained no peer information and therefore served as a control condition. For the QE recipients, the two peer information mailings stated the fraction of employees in the relevant age bracket who were already enrolled in the savings plan. For the EE recipients, the two peer information mailings stated the fraction of savings plan participants in the relevant age bracket contributing at least $6 \%$ of their pay on a before-tax basis to the plan.

Employees in our study naturally fall into four subpopulations distinguished along two dimensions: QE recipients versus EE recipients, and employees who were automatically enrolled at a $6 \%$ contribution rate unless they opted out (non-union workers at this firm) versus employees who were not enrolled unless they opted into the plan (union workers at this firm). Table I summarizes the key features of these four subpopulations. We distinguish along the first dimension because the QE and EE mailings make different requests of recipients: initial enrollment at a pre-selected contribution rate and asset allocation in the case of QE, and only an increase to the pre-selected contribution rate in the case of EE. The second dimension is important because it affects selection into our sample. Employees with a $6 \%$ contribution rate default had to actively opt out of their default to a contribution rate below $6 \%$ in order to be eligible for QE or EE, so no QE or EE recipient with this default was completely passive before the mailing. Similarly, employees with a $0 \%$ contribution rate default had to opt out of their default to a positive contribution rate below $6 \%$ in order to become eligible for EE. ${ }^{5}$ But in order to be eligible for $\mathrm{QE}$, employees with a $0 \%$ contribution rate default had to be completely passive. This last subpopulation contains some employees who genuinely wanted to contribute

\footnotetext{
${ }^{5}$ If they later returned their contribution rate to $0 \%$, they would still be eligible for EE.
} 
nothing to the $401(\mathrm{k})$ and some employees who were contributing nothing simply because of inertia. Prior research shows that the inertial group is likely to be large (Madrian and Shea, 2001; Choi et al., 2002 and 2004; Beshears et al., 2008). ${ }^{6}$ Because people who are contributing nothing to the $401(\mathrm{k})$ simply because of inertia are likely to have weaker convictions about their optimal savings rate than people who have actively chosen to contribute little, we expected QE recipients with a $0 \%$ contribution rate default to be the subpopulation most susceptible to the peer information intervention that we studied.

In the taxonomy of Harrison and List (2004), our study is a "natural field experiment," since subjects never learned that they were part of an experiment. We use administrative plan data to track contribution rate changes during the month following our mailing.

We measure the average effect of the presence of peer information by comparing how much more the peer information treatment groups increased their contribution rates than the control group. We also independently estimate the effect of the magnitude of the peer information value that employees saw. To do this, we exploit two sources of variation in the peer information value. First, two employees of the same age were exposed to different peer information values if one was randomly assigned to see information about coworkers in her fiveyear age bracket and the other to see information about coworkers in her ten-year age bracket. Second, two employees who are similar in age but on opposite sides of a boundary separating adjacent five-year or adjacent ten-year age brackets would see different peer information values.

We find that among QE recipients with a $0 \%$ contribution rate default - those whom we expected to be most susceptible to our information treatment-receiving peer information significantly reduced the likelihood of subsequently enrolling in the plan from $9.9 \%$ to $6.3 \%$, a decrease of approximately one-third. These recipients' enrollment was also decreasing in the magnitude of the peer information value communicated. A one percentage point increase in the reported fraction of coworkers already enrolled in the plan significantly reduced the enrollment rate by 1.8 percentage points and significantly reduced the average before-tax contribution rate change by $0.11 \%$ of income (which is one-fifth of the average contribution rate change among control QE recipients with a $0 \%$ contribution default).

\footnotetext{
${ }^{6}$ Prior to the mailing, the plan participation rate was $70 \%$ for employees with a non-enrollment default and $96 \%$ for employees with a $6 \%$ contribution rate default. The latter figure does not include employees with less than 90 days of tenure, since they are likely to have had automatic enrollment pending.
} 
We do not find statistically significant evidence that the peer information intervention on average altered the savings behavior of the other three subpopulations that had previously opted out of their default. There is some indication (at the $10 \%$ significance level) that the magnitude of the peer information value reported matters for these subpopulations. Among $\mathrm{QE}$ recipients who had previously opted out of a $6 \%$ contribution rate default, a one percentage point increase in the reported fraction of coworkers already enrolled in the plan increased the enrollment rate by 1.1 percentage points and increased the average before-tax contribution rate change by $0.06 \%$ of income; both of these changes are about 1.5 times the relevant control group mean. Among EE recipients who had opted out of a $6 \%$ contribution rate default, a one percentage point increase in the reported fraction of participants contributing at least $6 \%$ of their pay to the plan increased before-tax contribution rate changes by $0.07 \%$ of income-about one-fourth of the relevant control group mean.

The finding that $\mathrm{QE}$ recipients with a $0 \%$ contribution rate default respond negatively to peer information by decreasing their likelihood of enrolling in the savings plan is surprising, but there is some precedent for perverse unintended "boomerang effects" (Clee and Wicklund, 1980; Ringold, 2002) from peer information interventions. Schultz et al. (2007) find that among households with low initial energy consumption, a treatment group that received information about the energy consumption of nearby residences engaged in less energy conservation than a control group that did not receive such information. ${ }^{7}$ Bhargava and Manoli (2011) document that households eligible for the Earned Income Tax Credit are less likely to take up the credit when they are told that overall take-up rates are high. ${ }^{8}$

Relative to these studies, an important contribution of our experiment is that it provides evidence distinguishing between two possible forces behind boomerang effects: negative belief updates and oppositional reactions. The boomerang effects in previous field experiments could be driven by negative belief updates - individuals learning that the promoted behavior is less

\footnotetext{
${ }^{7}$ Allcott (2011), Costa and Kahn (2013), and Ayres, Raseman, and Shih (2013) also examine household responses to information about neighbors' energy consumption, but they do not find boomerang effects.

${ }^{8}$ In related studies, Fellner, Sausgruber, and Traxler (2013) document that peer information regarding tax compliance can have positive or negative effects on compliance depending on the subpopulation studied. Carrell, Sacerdote, and West (2013) find unintended effects in another kind of peer intervention that attempted to use peer influence to improve the academic performance of the lowest ability students. Ashraf, Bandiera, and Lee (2014) find that the anticipation of relative performance information reduces performance among low ability students in a community health worker training program.
} 
common than they previously believed and decreasing their own engagement in the behavior as a result (Schultz et al., 2007). In contrast, it is unlikely that our boomerang effects are driven by negative belief updates. Using randomized variation in the peer participation value shown to individuals, we find that QE recipients with a $0 \%$ contribution rate default are less likely to enroll in the savings plan when they see that a higher fraction of their peers are participating in the plan. Instead of shifting their behavior towards their updated beliefs about the peer norm, individuals shift their behavior away from the updated beliefs. We label such a response an oppositional reaction.

We analyze treatment effect heterogeneity to better understand the drivers of oppositional reactions. Motivated by recent evidence that relative income comparisons within workplace peer groups can reduce job satisfaction for low-income workers (Card et al., 2012), we split employees in our experiment into two groups based on whether they are above or below the median income of the firm's employees in the given employee's U.S. state. We find that the oppositional reaction among QE recipients with a $0 \%$ default is concentrated among employees with low relative incomes. This result raises the possibility that information about peers' savings choices discourages low-income employees by making their relative economic status more salient, reducing their motivation to increase their savings rates and generating an oppositional reaction. Employees with low relative income in the experiment's other three subpopulations also exhibit more negative responses to peer information than employees with high relative income, although the statistical significance of these interactions is not as strong. In addition, we find evidence that some employees become discouraged when they learn that a savings rate that they find challenging has already been attained by many of their peers.

Discouragement from upward social comparisons is unlikely to be the only factor that drives oppositional reactions, but it should be a consideration for policymakers or managers contemplating peer information interventions because it is potentially present in other contexts given the ubiquity of relative status concerns. Our field experiment highlights one channel through which the unintended consequences of financial decision-making interventions can overwhelm the intended consequences (see also Carlin, Gervais, and Manso, 2013).

The paper proceeds as follows. Section I provides background information on the firm we study. Section II describes our experimental design, and Section III describes our data. Section 
IV presents our empirical results, and Section V discusses possible mechanisms driving our findings. Section VI concludes.

\section{Company Background}

The company that ran our field experiment is a manufacturing firm with approximately 15,000 U.S. employees. About a fifth of the employees are represented by one of five unions. In general, unionized workers are employed on the manufacturing shop floor, although not all shop floor workers are unionized. The firm offers both defined benefit (DB) and defined contribution (DC) retirement plans to its employees. The details of the DB plans vary according to an employee's union membership, but a typical employee receives an annual credit of $4 \%$ to $6 \%$ of her salary in a cash balance plan, as well as interest credit on accumulated balances. Upon retirement, the employee receives an annuity based on the notional balance accrued in the plan.

The details of the DC plan, which is the focus of our study, also depend on an employee's union membership. In general, employees do not need to meet a minimum service requirement before becoming eligible for the plan. Participants can contribute up to $50 \%$ of their eligible pay to the plan on a before-tax basis, subject to IRS limits. ${ }^{9}$ For most employees, the firm makes a matching contribution proportional to the employee's own before-tax contribution up to a threshold. These matching contributions vest immediately. Table II describes the matching formulas that apply to different employee groups. After-tax contributions to the plan are also allowed but not matched. All employees can allocate plan balances among 21 mutual funds, eleven of which are target date retirement funds. Employer stock is not an investment option.

On January 1, 2008, all non-union employees not already contributing to the 401(k) plan were automatically enrolled at a before-tax contribution rate of $6 \%$ of pay unless they opted out or elected another contribution rate. ${ }^{10}$ The default investment for automatically enrolled employees was the target date retirement fund whose target retirement date was closest to the employee's anticipated retirement date. Non-union employees hired after January 1, 2008 were also subject to automatic enrollment 60 days after hire unless they actively opted out. Automatic enrollment was not implemented for unionized employees until January 1, 2009—after our

\footnotetext{
${ }^{9}$ In 2008 , the year of the experiment, the annual contribution limit was $\$ 15,500$ for workers younger than 50 and $\$ 20,500$ for workers older than 50 .

${ }^{10}$ Employees were informed in advance that they would be automatically enrolled unless they opted out.
} 
sample period ends - because the collective bargaining negotiations necessary to effect the change did not take place until the fall of 2008.

\section{Experimental Design}

The peer information intervention targeted non-participating and low-saving U.S. employees who were at least 20 years old and at most 69 years old as of July 31, 2008. "Nonparticipants" were defined as employees who were eligible for but had never enrolled in the 401(k) plan as of July 14, 2008. Two groups of non-participants were excluded from the intervention. The first group is employees who receive a special pension benefit in lieu of an employer match. ${ }^{12}$ The second group is employees with a $6 \%$ default contribution rate who were within the first 60 days of their employment at the company on July 14, 2008 and had not opted out of automatic enrollment; these employees were likely to be automatically enrolled soon after the intervention date, so the intervention would serve little purpose for them. "Low savers" were defined as employees who were enrolled in the 401(k) plan but whose before-tax contribution rate was less than both their employer match threshold and $6 \%$ as of July $14,2008 .{ }^{13}$ The majority of employees in our experiment $(72 \%)$ have a match threshold of $6 \%$, but the match threshold varies by union status and is less than $6 \%$ for some unionized employees and greater than $6 \%$ for others (see Table II). ${ }^{14}$

We used a stratified randomization scheme to allocate intervention-eligible employees to three equally sized treatment groups. We first sorted employees into bins based on age as of July 31, 2008, plan participation status (enrolled or not enrolled), administrative grouping within the firm, and employer match structure (and therefore union status and contribution rate default).

\footnotetext{
${ }^{11}$ Employees younger than 20 or older than 69 years of age were excluded from the intervention because there are so few employees in these categories that reporting peer information about these age groups could potentially divulge the savings decisions of individual employees.

${ }^{12}$ Only 52 employees receive this special pension benefit but otherwise met the criteria for inclusion in the intervention.

${ }^{13}$ We did not consider after-tax contribution rates when classifying low savers. Approximately $9 \%$ of plan participants make after-tax contributions, and approximately $9 \%$ of the employees we classified as low savers were making after-tax contributions at the time of the experiment. If we had limited the intervention to employees whose combined before-tax and after-tax contribution rates were less than both their employer match threshold and $6 \%$, approximately $7 \%$ of the low savers would have been excluded.

${ }^{14}$ One match formula limits employer matching contributions to a maximum of $\$ 325$ per year. We did not observe the dollar amount of matching contributions as of July 14, 2008, so the definition of low savers did not exclude employees who had reached the maximum. The results of our analysis do not change meaningfully if all low savers who faced this match formula are dropped from the sample.
} 
Within each of these bins, employees were randomly assigned to receive no peer information, information about the savings behavior of peers in their five-year age bracket, or information about the savings behavior of peers in their ten-year age bracket. Note that all of the 5-year brackets had end points at ages 24, 29, 34, etc. In other words, all subjects between ages 20 and 24 in the 5-year peer treatment saw the same peer information. Likewise, all of the 10-year brackets had end points at ages 29, 39, 49, etc. In other words, all subjects between ages 20 and 29 in the 10-year peer treatment saw the same peer information. Psychology research indicates that the effect of social comparisons on behavior is most powerful when the reference group is similar to the target individual on one or more dimensions, such as age (Jones and Gerard, 1967; Suls and Wheeler, 2000).

On July 30, 2008, Quick Enrollment and Easy Escalation mailings were sent to target employees, implying that employees probably received these mailings between August 1 and August 4, 2008. Both the QE and EE mailings gave a deadline of August 22, 2008 for returning the forms, but this deadline was not enforced. Appendices A, B, C, and D show sample QE and EE letters.

Non-participants received a QE mailing, which described the benefits of enrollment in the 401(k) plan, especially highlighting the employer matching contribution. ${ }^{15}$ By checking a box on the form, signing it, and returning it in the provided pre-addressed postage-paid envelope, employees could begin contributing to the plan at a $6 \%$ before-tax rate invested in an age-linked target date retirement fund. Employees were reminded that they could change their contribution rate and asset allocation at any time by calling their benefits center or visiting their benefits website. The mailing sent to employees in the peer information treatments additionally displayed the following text: "Join the $A \%$ of $B-C$ year old employees at [company] who are already enrolled in the [plan]." Letters sent to employees in the no peer information control condition simply omitted this sentence. The number $A$ was calculated using data on all savings-planeligible employees in the five-year or ten-year age bracket applicable to the recipient. These participation rates, reported in Table III, ranged from $77 \%$ to $93 \%$. The numbers $B$ and $C$ are the boundaries of the relevant five-year or ten-year age bracket.

\footnotetext{
${ }^{15}$ Information on employer contributions varied according to the match structure facing the individual employee.
} 
Low savers received EE mailings, which also emphasized that employees were forgoing employer matching contributions. ${ }^{16} \mathrm{~A}$ low-saving employee could increase her before-tax contribution rate to $6 \%$, invested according to her current asset allocation, by completing the form and returning it in the provided pre-addressed postage-paid envelope. Like the QE mailings, the EE mailings reminded recipients that they could change their contribution rate or asset allocation through their benefits call center or website. The EE peer information text, which did not appear in the mailings to employees in the no peer information control condition, read: "Join the $D \%$ of $B-C$ year old [plan] participants at [company] who are already contributing at least $6 \%$ to the [plan]." Data on all plan participants in the relevant five-year or ten-year age bracket were used to calculate $D$, which ranged from $72 \%$ to $81 \%$ (see Table III).

Due to technological constraints in the processing of QE and EE forms, all QE and EE reply forms offered only a $6 \%$ contribution rate option. Every employee with a $6 \%$ contribution rate default had a $6 \%$ match threshold, but the match threshold differed from $6 \%$ for $77 \%$ of mailing recipients with a $0 \%$ contribution rate default. The $6 \%$ contribution rate on the $\mathrm{QE}$ and EE forms could have been less appealing to employees with a different match threshold. Within the group of recipients with a $0 \%$ default, we have analyzed those with a match threshold other than $6 \%$ separately from those with a match threshold of $6 \%$. The peer information treatment effect estimates are similar across these subsamples, although the standard errors of the estimates for the $6 \%$ threshold group are large because of the small sample size.

\section{Data}

Our data were provided by Aon Hewitt, the 401(k) plan administrator. The data include a cross-sectional snapshot of all employees in our experiment on July 14, 2008, just prior to our intervention. This snapshot contains individual-level data on each employee's plan participation status, contribution rate, birth date, administrative grouping within the firm, employer match structure, union membership, and contribution rate default. A second cross-section contains the new plan enrollments and contribution rate changes of employees between August 4, 2008 and September 8, 2008-right after the mailing was sent. The final cross-section contains employees' gender, hire date, and 2008 salary, which we annualize for employees who left the firm before

\footnotetext{
${ }^{16}$ Again, information about employer contributions was personalized.
} 
the end of 2008. In Section V, when we analyze treatment effect heterogeneity, we augment our data set with information on the state of residence and 2008 salary of all employees who were active at the firm (including those not in our experiment) as of July 14, 2008, as well as information on the monthly history of before-tax contribution rates for each employee.

\section{Effects of Providing Peer Information}

We divide the discussion of our main empirical results into five parts. First, in Section IV.A, we discuss the characteristics of the employees who received mailings. Second, in Section IV.B, we analyze the effect of providing peer information in the QE mailing by comparing the savings choices of peer information QE treatment groups to those of the control group that received the QE mailing with no peer information. Third, in Section IV.C, we restrict our attention to the peer information QE treatment groups and examine the response to the magnitude of the peer information value in the mailing. Fourth, in Section IV.D, we examine the impact of the peer information given in the EE mailings. And finally, in Section V, we discuss possible explanations for the perverse peer information effects we observe among QE recipients with a $0 \%$ contribution rate default.

\section{A. Employee Characteristics}

Table IV presents summary statistics for the sample that received mailings, broken out by the type of mailing (QE or EE), contribution rate default ( $0 \%$ or $6 \%)$, and the type of peer information received. The majority of the sample is male, although this fraction varies considerably across the different subpopulations: 66\% among QE recipients with a 0\% default, 76\% among QE recipients with a 6\% default, 55\% among EE recipients with a $0 \%$ default, and $68 \%$ among EE recipients with a $6 \%$ default. The average age is 41 years, and average tenure is high —9 years among QE recipients with a 0\% default, 7 years among QE recipients with a 6\% default, and 11 years in both EE subpopulations. Mean annual salary is lowest among QE recipients with a $0 \%$ default (about $\$ 38,000$ ) and highest among EE recipients with a $6 \%$ default (about $\$ 57,000$ ). Issues surrounding relative salaries may play a role in explaining differences in responses to peer information across the four groups, a topic to which we return in Section V. Among the two EE subpopulations, average initial before-tax contribution rates are about $2 \%$. 


\section{B. Effect of Providing Peer Information in Quick Enrollment}

To estimate the effect of providing peer information in the QE mailing, we compare the savings choices of peer information QE treatment groups to those of the control group that received no peer information. The first two columns of Table V list, by contribution rate default, the fraction of employees in each QE treatment group who enrolled in the savings plan between August 4, 2008 and September 8, 2008. The last two columns report the average before-tax contribution rate change during the same time period as a percent of income for each QE treatment group, again broken out by contribution rate default. ${ }^{17}$ Note that the contribution rate changes are almost exactly equal to $6 \%$ of the enrollment rates because the QE response cards do not permit contribution rates other than $6 \% .{ }^{18}$ We report results both in terms of enrollment rates and in terms of contribution rate changes because the two measures are both useful for understanding economic magnitudes. In addition, we wish to be consistent with our presentation of the EE subpopulation results, for which the simple relationship between the two measures does not hold. To statistically test the effect of providing peer information, we pool the five-year and ten-year age bracket peer information treatments (row 4 of Table V).

We first look at the non-participants with a $0 \%$ contribution rate default. This is the subpopulation that we expected to have the most malleable retirement savings choices. Among this group, $6.3 \%$ of employees who were given peer information enrolled in the plan, while $9.9 \%$ of those whose mailings did not include peer information enrolled in the plan, a statistically significant difference of 3.6 percentage points. This implies that peer information provision reduces savings plan enrollment by a third. The difference in enrollment rates corresponds to a 20 basis point reduction in the average before-tax contribution rate change as a percent of income, a difference that is significant at the $10 \%$ level.

In contrast, we do not find evidence that providing peer information on average affects non-participants who previously opted out of automatic enrollment at a $6 \%$ default contribution rate. There was a $2.7 \%$ enrollment rate and a 15 basis point before-tax contribution rate increase within the pooled peer information treatments versus a $0.7 \%$ enrollment rate and a 4 basis point

\footnotetext{
${ }^{17}$ Individuals who ceased employment at the firm between August 4, 2008 and September 8, 2008 are treated as if their participation status and contribution rate on their departure date continued unchanged until September 8, 2008. ${ }^{18} \mathrm{QE}$ recipients could choose alternative contribution rates by using the benefits website or calling the benefits office, but the QE response card was probably more convenient.
} 
before-tax contribution rate increase within the control group without peer information. The differences between these two arms are not statistically significant.

Table VI analyzes the average effect of providing peer information in the QE mailings within an ordinary least squares regression framework. The sample is non-participants who received QE mailings. In the first two columns, the dependent variable is binary, taking a value of one if the employee initiated savings plan participation between August 4, 2008 and September 8,$2008 ;{ }^{19}$ in the next two columns, the dependent variable is the change in the employee's before-tax contribution rate during the same time period. The regressions control for gender, log tenure, log salary, and a linear spline in age with knot points every five years starting at age $22 \frac{1}{2} .^{20}$ The regression-adjusted impact of providing peer information is qualitatively and quantitatively similar to the effect estimated from comparing means in Table V. Including peer information decreases enrollment by 4.0 percentage points and reduces the change in the beforetax contribution rate by 22 basis points for non-participants with a $0 \%$ contribution rate default, while it has positive but insignificant effects on non-participants with a $6 \%$ contribution rate default. Interestingly, for QE recipients with a $0 \%$ default, the regression coefficients on log tenure are strongly negative. For QE recipients with a 6\% default, the regression coefficients on log tenure are also negative but not statistically significant. One possible interpretation for this result is that individuals who have been employed at the firm for a long time but have never enrolled in the savings plan are people who strongly believe that it is not optimal for them to participate in the plan.

\section{Effect of the Peer Information Value's Magnitude in Quick Enrollment}

To examine how the magnitude of the peer information value received by employees affected responsiveness to the QE mailing, we limit our attention to the employees who were in the two peer information QE treatments. An important confound our analysis must address is the

\footnotetext{
${ }^{19}$ We report the estimates from linear probability regressions for the binary dependent variables instead of probit or logit regressions because of problems with perfect predictability. Our flexible age controls sometimes perfectly predict failure, requiring us to drop observations from probit or logit regressions. Adjusting the sample for each regression specification would make it difficult to compare results across specifications, and using a common minimal sample for all specifications could potentially give a misleading picture of the results. Thus, we report the results of linear probability regressions, which allow us to maintain a consistent sample and include all observations. ${ }^{20}$ As noted in Table IV, salary information is missing for a small number of employees. We exclude these employees from regression samples throughout the paper. We use a linear spline in age instead of age group dummy variables in Table VI to be consistent with Table VII.
} 
"reflection problem" (Manski, 1993). Because our experiment provided employees with peer information related to their five-year or ten-year age brackets, the peer information value embeds not only information about the peer group but also information about the age-related characteristics of the mailing recipient. Throughout our analysis, we therefore study the relationship between responsiveness to the mailing and the magnitude of the peer information value while controlling for a flexible function of age - specifically, an age spline with knot points every five years starting at age $221 \frac{1}{2}$.

Our empirical strategy identifies the effect of the peer information value's magnitude using two sources of variation. First, two employees of the same age may see different peer information values if one is randomly assigned to receive information about her five-year age bracket and the other is randomly assigned to receive information about her ten-year age bracket. Second, two employees who are nearly identical in age may see different peer information values if their ages are on opposite sides of a boundary separating two adjacent five-year or ten-year age brackets.

Table VII presents results from our baseline regression specification for analyzing the impact of the peer information value's magnitude. The coefficient estimates are from ordinary least-squares regressions for the sample of non-participants who received QE mailings with peer information. The outcomes of interest are the same as in Table VI-enrollment in the savings plan or the change in the employee's before-tax contribution rate between August 4, 2008 and September 8, 2008 - as are the other regression controls.

For non-participants with a $0 \%$ contribution rate default, a one percentage point increase in the reported fraction of coworkers participating in the plan results in a statistically significant 1.8 percentage point decrease in the probability of enrolling in the plan and a statistically significant 11 basis point lower change in the before-tax contribution rate. To put these estimates in perspective, the peer information values received by non-participants range from $77 \%$ to $93 \%$, a difference of 16 percentage points (Table III). This implies an enrollment rate and before-tax contribution rate change that differ by 28 percentage points and $1.7 \%$ of income, respectively, between employees who receive the lowest and the highest peer information values - a very large difference relative to the $9.9 \%$ enrollment response and $0.6 \%$ before-tax contribution rate change of QE recipients with a $0 \%$ default who received no peer information (Table V). Note that these estimates cannot be directly compared to the estimates in Table VI, as the regressions 
reported in Table VI measure the effect of the presence of peer information, while the regressions reported in Table VII measure the effect of the magnitude of the peer information value received, conditional on receiving peer information.

In contrast, among non-participants with a $6 \%$ default, a one percentage point increase in the peer information value results in a 1.1 percentage point increase in the enrollment rate and a 6 basis point higher increase in the contribution rate, although these effects are significant only at the $10 \%$ level. Note the complementarity of the results in Tables VI and VII. For nonparticipants with a $0 \%$ default, receiving peer information reduces the response rate to the $\mathrm{QE}$ mailings on average (Table VI), and receiving a peer information value with a higher magnitude further reduces the QE response rate (Table VII). For QE recipients with a 6\% default, receiving peer information leads to a small but insignificant increase in the response rate on average (Table VI), and the response rate also increases in the magnitude of the peer information value (Table VII).

Table VIII shows the importance of the two sources of variation in the peer information value used to generate the results in Table VII. To facilitate comparison, the first column reproduces the peer information value coefficient estimates from Table VII. The coefficients in the second column of Table VIII are estimated by adding to the baseline regression specification a set of five-year age bracket dummies that correspond to the age brackets in the five-year age bracket peer information treatment. With the inclusion of these dummies, the effect of the peer information value is no longer identified using discontinuities across age bracket boundaries; rather, identification comes entirely from differences between employees in the five-year versus ten-year age bracket peer information treatments. The peer information coefficients in this specification are slightly larger than in the baseline specification and retain the same qualitative level of statistical significance.

The regression specification presented in the last column of Table VIII excludes the fiveyear age group dummies used in the second column and instead estimates different linear splines in age for employees in the five-year versus ten-year age bracket peer information treatments. Here, identification comes only from comparing employees on opposite sides of an age bracket boundary at which the peer information value jumps discontinuously. Under this specification, the peer information value coefficients do not change sign, but they are smaller in magnitude and lose their statistical significance. Hence, the effects estimated in the baseline specification from 
Table VII are largely driven by the differences in peer information values between the five-year and ten-year age bracket peer information treatments.

In Table IX, we investigate the robustness of our peer information value results to the manner in which we control for age in our regressions. The first row presents the peer information value coefficients from our baseline specifications in Table VII to facilitate comparison. In the second row, we replace the original linear spline (knot points every five years) with a linear spline featuring knot points every $2 \frac{1}{2}$ years, starting at age $22 \frac{1}{2}$. This spline is more flexible and hence gives a sense of whether the structure imposed by the original spline produces misleading results. The coefficients on the peer information value do not change meaningfully with the more flexible spline, and their statistical significance strengthens for employees with a $6 \%$ contribution rate default.

One additional element that varied across the QE mailings was the fund in which employee contributions would be invested absent any other election by the employee. (This was not a factor in the EE mailings, since all employees currently contributing to the plan had a preexisting asset allocation.) This default fund was a target date retirement fund (e.g., Fund 2020) chosen according to the recipient's anticipated retirement age and thus varying systematically with age. Although we think it is unlikely that employees would respond to the mailings differentially depending on the target date retirement fund offered, we nonetheless try to account for this possibility by including dummy variables in the regressions for the exact target date retirement fund mentioned in the mailings. As shown in the third row of Table IX, incorporating these controls does not change our main results.

The specifications in the last two rows of Table IX are designed to address another set of issues. The two sources of identifying variation in the peer information value are associated with an employee's position within an age bracket. Two employees of the same age who are randomly assigned to the five-year versus ten-year age bracket peer information treatments differ not only in the peer information values they see, but also in the set of peers for whom those values are defined, with one group (the five-year group) more narrowly defined than the other. Similarly, two employees on opposite sides of a boundary separating adjacent five-year or ten-year age brackets are exposed to different peer information values but are also in different situations relative to their peer groups, with one older than most of her peer group and the other younger. To partially control for these factors, we add to our regressions variables capturing an 
individual's position relative to her peer information comparison group. The regressions reported in the fourth row of Table IX include linear and squared terms for the difference in years between the employee's age and the mean age in her peer group; the regressions reported in the fifth row of Table IX include linear and squared terms for the employee's percentile rank in age within her peer group. All coefficient estimates for the QE recipients with a $0 \%$ contribution rate default are qualitatively similar to the baseline coefficient estimates. For the QE recipients with a $6 \%$ contribution rate default, the coefficients remain similar in magnitude but lose significance even at the $10 \%$ level when we control for the difference between the employee's age and her peer group's mean age.

\section{Effect of Providing Peer Information in Easy Escalation}

We now turn our attention to the impact of providing peer information to the low savers who received the EE mailings. The first two columns of Table $X$ list the fraction of low savers, separately by their contribution rate default, who increased their before-tax contribution rate between August 4, 2008 and September 8, 2008. The last two columns of Table X report the average before-tax contribution rate change during the same time period. The last row in Table $\mathrm{X}$ shows that the differences between the groups who did and did not receive peer information are close to zero and insignificant for both $0 \%$ and $6 \%$ default contribution rate participants.

Table XI reports the OLS-adjusted average impact of providing peer information in EE. In the first two columns, the dependent variable is a binary variable taking a value of one if the employee increased her before-tax contribution rate between August 4, 2008 and September 8, 2008; in the next two columns, the dependent variable is the change in the employee's before-tax contribution rate during the same time period. In addition to the controls used in Table VI for the QE recipients, the regressions for the EE recipients include a full set of indicator variables for each employee's before-tax contribution rate on July 14, 2008-two weeks prior to the mailing. The results in Table XI are qualitatively similar to the raw differences reported in Table X: receiving peer information has a negligible and statistically insignificant effect on savings responses on average.

Table XII presents regressions that identify the impact of the peer information value's magnitude in the EE mailings. The dependent variables are the same as in Table XI. As we did in the corresponding analysis for $\mathrm{QE}$, we restrict the regression sample to EE recipients who were 
given peer information. We find that the peer information value's magnitude has a positive but insignificant effect on the probability of increasing one's before-tax contribution rate. The peer information value's magnitude also has an insignificant effect on the before-tax contribution rate change for recipients with a $0 \%$ contribution rate default, but a positive and marginally significant effect for recipients with a $6 \%$ contribution rate default. For the latter group, a one percentage point increase in the peer information value results in a 7 basis point higher increase in the before-tax contribution rate.

\section{Mechanisms Driving the Effects of Peer Information}

The negative response of non-participants with a $0 \%$ contribution rate default (unionized employees) to the peer information in QE mailings is surprising. This contrary reaction is probably not due to learning that coworkers had a lower plan participation rate than expected, since the enrollment rate and contribution rate changes of non-participants with a $0 \%$ default varied inversely with the magnitude of the peer information value they received. Instead, the boomerang effect among QE recipients with a $0 \%$ default appears to be an oppositional reaction.

In this section, we discuss the mechanisms that may be driving the oppositional reaction. The evidence suggests that peer information is discouraging and demotivating for some subpopulations of employees. In particular, discouragement from being compared to peers who have higher economic status seems to play a role, as the negative response to peer information is concentrated among individuals who have salaries that are low in the pay distribution of the firm's employees in the individual's state. There is also some evidence that employees can be discouraged when a goal that is difficult for them to attain is revealed to be a goal that many peers have achieved. EE recipients with a $0 \%$ default reacted more negatively to peer information if they initially had a low contribution rate rather than a high contribution rate, making the goal of increasing to a $6 \%$ contribution rate harder to reach.

Our experiment was not specifically designed to test these explanations for the effect of peer information, so our analysis of treatment effect heterogeneity must be interpreted with caution. Nonetheless, issues of low relative status and difficult-to-achieve goals arise naturally in many settings, so this pattern of responsiveness is potentially relevant for other contexts in which peer information interventions might be deployed. 


\section{A. Relative Salary and Discouragement from Peer Information}

Recent research by Card et al. (2012) indicates that job satisfaction is affected by an employee's rank within the salary distribution of that employee's peers. Card et al. randomly assigned employees of the University of California to receive or not to receive information about a website that disclosed the pay of all University of California employees. Among employees below the median pay for their occupation category (i.e., faculty versus staff) within their department, the information treatment had a negative effect on job satisfaction, while there was no significant effect for employees above the median pay for their occupation category within their department. Relative pay concerns are quite local. For staff (who constitute over $80 \%$ of the sample), being below the campus-wide median staff pay had smaller negative effects than being below their department's median staff pay.

Drawing on these findings, we test how the peer information effect in our experiment varies with an employee's salary rank among local coworkers. ${ }^{21}$ Employees are likely to have some knowledge, through both formal and informal workplace communication channels, of their positions in the local pay distribution at the firm. Having one's savings choices compared to coworkers' savings choices in our experiment may serve as a reminder of relative economic standing, creating feelings of discouragement and thereby triggering an oppositional reaction among employees with low relative income. Larger peer savings numbers would exacerbate discouragement by increasing the size of the perceived economic gap between the low-income employee and his coworkers. ${ }^{22}$

Our data are not as detailed as the University of California data, so we calculate an employee's rank within the salary distribution for all employees at the firm in the same state. ${ }^{23}$ This peer group includes employees who were not part of our experiment but excludes employees who were not active at the firm as of July 14, 2008. Two states account for half of the

\footnotetext{
${ }^{21}$ We thank an Associate Editor for suggesting this analysis.

${ }^{22}$ One might wonder why a higher peer information number wouldn't also create more discouragement among highincome employees. See Price et al. (1994) and Sloman, Gilbert, and Hasey (2003) for a discussion of why negative information is more likely to discourage people who are already low-status to begin with.

${ }^{23} \mathrm{We}$ do have some limited information about administrative groupings at the firm, but these groupings do not appear to correspond to meaningful peer groups. Nonetheless, we have calculated salary rank within administrative grouping and experimented with using it for analyzing heterogeneous treatment effects. In general, the results are directionally similar but attenuated relative to the results using salary rank among employees at the firm within the same state.
} 
employees in the experiment, but 23 other states account for the remaining employees. ${ }^{24}$ Internet Appendix Table I reports the distribution of employees in our experiment across within-state income quartiles. Employees in our experiment disproportionately fall in the lower quartiles of the distribution, especially in the case of employees with a $0 \%$ default.

We begin by studying the reaction to peer information among QE recipients with a $0 \%$ default. To estimate heterogeneity in the effect of the presence of peer information, we augment the regression specifications from Table VI with two additional explanatory variables: an indicator for being below the median income among active employees at the firm in the same state and the interaction between that indicator and the indicator for receiving peer information. The first two columns of Table XIII display the results.

The coefficients on the uninteracted dummy for receiving peer information show that $\mathrm{QE}$ recipients with a $0 \%$ default and high relative income have a small positive but insignificant response to the presence of peer information. The coefficient on the interaction term, however, is negative and statistically significant at the $10 \%$ level in both columns. Peer information causes QE recipients with a 0\% default and low relative income to decrease their enrollment rate by 5.2 percentage points more and decrease their before-tax contribution rate by 29 basis points of pay more than $\mathrm{QE}$ recipients with a $0 \%$ default and high relative income.

Turning to heterogeneity in the effect of the peer information value's magnitude in Quick Enrollment, we expand the set of explanatory variables in the Table VII regression specifications to include the indicator for having an income below the median among active employees at the firm in the same state, the interaction between the below-median income indicator and the peer information value received (the participation rate among employees in the relevant age group), and the interaction between the below-median income indicator and all elements of the age spline. It is necessary to allow separate age splines for the high and low relative income employees so that the effect of the peer information value is identified only using variation generated by discontinuities around age group boundaries and differences between the five-year and ten-year age group peer information values.

The last two columns of Table XIII show that for QE recipients with a $0 \%$ default and high relative income, a one percentage point increase in the peer information value increases the

\footnotetext{
${ }^{24}$ We do not know the state of three employees in our experiment, so we assign them to the most common state.
} 
likelihood of enrolling in the savings plan by 1.0 percentage point and increases the before-tax contribution rate change by 6 basis points of pay, although neither effect is statistically significant. For low relative income employees, however, the effect of a one percentage point increase in the peer information value is 2.8 percentage points more negative for the likelihood of enrolling and 17 basis points more negative for the before-tax contribution rate change. Both of these interactions are statistically significant at the 5\% level.

In sum, the oppositional reaction we identified among QE recipients with a $0 \%$ default is present only among employees with low income relative to other employees at the firm in the same state. This pattern suggests that discouragement from upward social comparisons may play a role in generating the oppositional reaction to peer information in our experiment. Further evidence in favor of this hypothesis is found in Table XIV, which shows that the treatment interactions with being in the bottom half of the firm-wide salary distribution are insignificant, with point estimates that are smaller in magnitude or of the opposite sign compared to the treatment interactions with being in the bottom half of the firm's state-specific salary distribution. Recall that Card et al. (2012) find that employees are most concerned about their salary rank relative to local coworkers, so vulnerability to discouragement from peer comparisons should depend more on where the employee stands in the local firm wage distribution than in the firm-wide wage distribution. Furthermore, employees are more likely to be unaware of their location in the firm-wide wage distribution than in the local wage distribution. We have also explored treatment interactions with being in the bottom half of the overall state-wide pay distribution (which includes individuals who do not work for the firm) and treatment interactions with having a salary below $\$ 30,000$. As shown in Internet Appendix Tables II and III, none of these interactions is significant.

Internet Appendix Tables IV through VII show analogous regressions for the other three subpopulations, QE recipients with a $6 \%$ default and EE recipients with a $0 \%$ or a $6 \%$ default. We generally find the same patterns of a negative peer information treatment interaction with having below-median income among other employees at the firm in one's state and a weaker treatment interaction with having below-median income in the firm-wide distribution. The interactions with having below-median income among other employees at the firm in one's state are not always statistically significant, but for each of the three subpopulations, there is at least one negative interaction with either the presence of peer information or the peer information 
value that is significant at the $10 \%$ level or better, and no significant positive interactions. One interesting pattern is that in these three subpopulations, unlike among QE recipients with a $0 \%$ default, being below the median local income does not tend to cause employees to move away from the peer norm. Rather it merely attenuates the positive reaction to peer information found among above-median-income employees. A possible interpretation of this difference is that the type of employee who takes an active role in his or her savings (and thus ends up in these three subpopulations) is less prone to discouragement from upward comparisons.

\section{B. Difficult Goals and Discouragement from Peer Information}

While discouragement caused by upward socioeconomic comparisons seems to contribute to negative reactions to peer information, discouragement driven by other related mechanisms may simultaneously be at work. In particular, the psychology literature documents that setting goals for individuals can motivate increased effort and achievement in tasks ranging from problem solving to wood chopping, especially when the goals are challenging (Locke et al., 1981; Mento, Steel, and Karren, 1987; Gollwitzer, 1999; Heath, Larrick, and Wu, 1999; Locke and Latham, 2002). But learning that a goal one finds extremely difficult has already been achieved by many of one's peers may damage one's self-esteem, making the goal feel more unattainable. When goals are too difficult, people are more likely to reject them and to perform poorly (Motowidlo, Loehr, and Dunnette, 1978; Mowen, Middlemist, and Luther, 1981; Erez and Zidon, 1984; Lee, Locke, and Phan, 1997).

We have no observable variation in how challenging QE recipients might have viewed the suggested $6 \%$ contribution rate to be, since all $\mathrm{QE}$ recipients had an initial contribution rate of $0 \%$. But EE recipients had starting contribution rates that varied from $0 \%$ to $5 \%$. We conjecture that EE recipients who initially had a lower contribution rate are more likely than EE recipients who initially had a higher contribution rate to view the suggested $6 \%$ contribution rate as a challenging goal. ${ }^{25}$ Internet Appendix Table VIII shows the contribution rate distribution of EE recipients with a $0 \%$ default and a $6 \%$ default immediately before the experiment was launched. The distributions are not perfectly uniform, but there is a meaningful number of

\footnotetext{
${ }^{25}$ We thank an anonymous referee for suggesting this analysis.
} 
employees in each sample at each contribution rate from $0 \%$ to $5 \%{ }^{26}$ We augment the regression specifications in Table XI by including the interaction between the indicator for receiving peer information and an indicator for having an initial contribution rate of $0 \%, 1 \%$, or $2 \%$. Indicators for each of the six possible initial contribution rates are already included as explanatory variables, omitting one to avoid collinearity with the constant.

In Table XV, columns 1 and 3 report the results for EE recipients with a $0 \%$ default, who are the EE group most similar to the QE recipients with a $0 \%$ default. Consistent with the hypothesis that the oppositional reaction among QE recipients with a $0 \%$ default is driven in part by peer information interacting negatively with a difficult suggested goal, the estimated coefficients on the interaction between the dummy for receiving peer information and the dummy for having a low initial contribution rate are negative and statistically significant at the 10\% level. Employees with high initial contribution rates respond to the presence of peer information with a 3.8 percentage point increase in their likelihood of increasing their contribution rates and an 18 basis points of pay increase in their before-tax contribution rate change. The former estimate is not statistically significant, and the latter estimate is significant at the 10\% level. Employees with low initial contribution rates have a response to peer information that is 8.7 percentage points more negative for the likelihood of a contribution rate increase and 38 basis points of pay more negative for the before-tax contribution rate change.

However, not all employees are demotivated when they learn that many of their peers have achieved a difficult goal. Columns 2 and 4 of Table XV show that EE recipients with a $6 \%$ default who have low initial contribution rates have a somewhat more positive response to peer information than EE recipients with the same default and high initial contribution rates. The effect on the binary indicator of whether the recipient increased his before-tax contribution rate is not significant, but the effect on the average before-tax contribution rate change is significant at the $10 \%$ level. For some subpopulations, learning that many peers achieved a challenging goal is perhaps an encouraging signal of one's own ability to achieve this goal.

In Internet Appendix Table IX, we examine the robustness of the findings in Table XV by estimating separate treatment effects from the presence of peer information for each of the six

\footnotetext{
${ }^{26}$ An employee with a $0 \%$ contribution rate is not considered a non-participant and therefore receives an Easy Escalation mailing instead of a Quick Enrollment mailing if that employee previously had a contribution rate higher than $0 \%$.
} 
possible initial contribution rates. The results broadly corroborate the patterns we observe when grouping the $0 \%, 1 \%$, and $2 \%$ contribution rates together and the $3 \%, 4 \%$, and $5 \%$ contribution rates together. We have also investigated how EE recipients with low initial contribution rates differ from EE recipients with high initial contribution rates in their responses to the magnitude of the peer information value. Internet Appendix Table $\mathrm{X}$ shows the results from regressions that expand the Table XII specifications by including the interaction between the dummy for having a low initial contribution rate and the peer information value as well as the interaction between the dummy for having a low initial contribution rate and all elements of the age spline. The results are consistent with the results for the effect of the presence of peer information. Among EE recipients with a $0 \%$ default, employees with a low initial contribution rate are more negatively responsive to the peer information value than employees with a high initial contribution rate, and among EE recipients with a $6 \%$ default, employees with a low initial contribution rate are slightly more positively responsive to the peer information value than employees with a high initial contribution rate. However, none of these interaction coefficients is statistically significant.

Overall, there is some evidence that for employees with a $0 \%$ default, the oppositional reactions we observe were caused in part by discouragement from learning that so many peers had achieved such a challenging goal. However, not all subpopulations are discouraged by the combination of more challenging goals and peer information.

\section{Other Factors that Might Affect the Response to Peer Information}

In this subsection, we consider other factors that may determine how individuals respond to peer information. We have previously argued that employees who have never made an active decision in the retirement savings plan (i.e., QE recipients with a $0 \%$ default contribution rate) may respond more to peer information because they have weaker convictions about what their savings rate should be. We now explore an extension of this argument: did EE recipients who had not recently made an active decision regarding their contribution rate as of the beginning of the experiment respond more to peer information? Such an association could exist if, for example, the type of person who is prone to be passive is also prone to have weak convictions about her optimal savings choice even after an active savings decision has been made at least once. 
For each EE recipient, we use data on monthly contribution rate histories to calculate the amount of time since the employee had last changed his or her before-tax contribution rate. For some employees, the last change took place when they initially enrolled in the plan. We then split employees into groups depending on whether the amount of time since their last change was above or below the median for their sample (the $0 \%$ default sample or the $6 \%$ default sample, as appropriate). In Internet Appendix Table XI, we add two explanatory variables to the Table XI regression specifications, which study the effect of the presence of peer information for $\mathrm{EE}$ recipients: an indicator for having an above-median time since the last contribution rate change and the interaction between that indicator and the indicator for receiving peer information. The estimated coefficients on these additional variables are small and never have a $t$-statistic greater than one in absolute value. It may be the case that once an employee has thought about his 401(k) enough to make an active savings decision, the strength of his conviction about optimal savings behavior in the plan does not covary with how long he remains at that contribution rate. ${ }^{27}$

Another factor that may have generated the oppositional response to peer information among QE recipients with a $0 \%$ default is the perception that one's optimal savings behavior is negatively correlated with that of the coworkers used to construct the peer information value. QE recipients with a $0 \%$ default were unionized employees, and because unionized employees constituted only one-fifth of the firm's workforce, company-wide 401(k) participation rates largely reflected the choices of non-union workers. If unionized employees identify themselves in opposition to non-union employees, they may prefer savings choices that are atypical by company standards. We have tried to examine this hypothesis empirically by testing whether the magnitudes of the peer information effects vary with the fraction of the peer reference group that is unionized. The results do not support the hypothesis.

Also, QE recipients with a $0 \%$ default may have believed, due to an antagonistic collective bargaining relationship with the firm, that savings messages sent by the company to unionized employees like them were likely to be counter to their own best interests. A related

\footnotetext{
${ }^{27} \mathrm{We}$ do not examine heterogeneity in treatment effects for QE recipients with a $6 \%$ default according to the amount of time since the last active decision because almost all employees in this sample last made an active decision when they opted out of automatic enrollment at the beginning of 2008. Only a handful of employees in this group were hired later in 2008 and opted out of automatic enrollment then.
} 
interpretation, in line with psychological reactance theory (Brehm, 1966), is that mistrust caused QE recipients with a $0 \%$ default to perceive the peer information as coercive, leading them to act contrary to the peer information in an effort to assert their independent agency. The weakness of this set of hypotheses is that it is not clear why the inclusion of peer information would produce greater mistrust than the control letter, which also strongly encouraged 401(k) participation, nor why mistrust would be increasing in the magnitude of the peer information value. Furthermore, while there have been occasional strikes at the firm, labor relations are not particularly strained, either in general or at the time of the experiment.

\section{Conclusion}

Our field experiment shows that exposure to information about the actions of peers can generate an oppositional reaction. Among the subpopulation we expected to be most susceptible to peer influence-employees not enrolled in the 401(k) plan who had a non-enrollment default (in this case, unionized employees) — we found a negative, oppositional reaction to both the presence of peer information and the magnitude of its value. On the other hand, employees who had actively chosen a low $401(\mathrm{k})$ contribution rate exhibited some positive reaction to the magnitude of the peer information value.

An analysis of treatment effect heterogeneity indicates that the oppositional reaction to peer information exhibited by Quick Enrollment recipients with a non-enrollment default was concentrated among employees with low incomes relative to their local coworkers. Thus, peer information may have made these employees less likely to increase their savings because they were discouraged by the reminder of their low economic status. We also find negative treatment interactions with low relative income in the other subpopulations in our experiment.

In settings where many individuals may not know which choices are appropriate for their circumstances, such as defined contribution savings plans, peer information interventions have a number of appealing features. If the choices of the average person are reasonable, individuals whose choices are in the extremes of the distribution can adjust upon learning about the typical behavior of peers. At the same time, peer information interventions are not coercive-individuals who are confident that it is appropriate for them to deviate from the peer norm are not forced to change their decisions. Our results, however, reveal an important drawback of highlighting the behavior of peers. Peer information inevitably contains an element of social comparison, and 
individuals with low status may react negatively to the information. A key issue for future research is to develop a better understanding of how peer information interventions can be shaped to minimize such oppositional reactions, perhaps by carefully selecting the reference group to minimize discouraging social comparisons.

\section{REFERENCES}

Abel, Andrew B., 1990, Asset prices under habit formation and catching up with the Joneses, American Economic Review 80, 38-42.

Akerlof, George A., 1980, A theory of social custom, of which unemployment may be one consequence, Quarterly Journal of Economics 94, 749-775.

Akerlof, George A., and Rachel E. Kranton, 2000, Economics and identity, Quarterly Journal of Economics 115, 715-753.

Ahern, Kenneth R., Ran Duchin, and Tyler Shumway, 2013, Peer effects in economic attitudes, Working Paper.

Allcott, Hunt, 2011, Social norms and energy conservation, Journal of Public Economics 95, 1082-1095.

Asch, Solomon E., 1951, Effects of group pressure upon the modification and distortion of judgments, in Harold Guetzkow, ed.: Groups, Leadership, and Men (Carnegie Press).

Ashraf, Nava, Oriana Bandiera, and Scott Lee, 2014, Awards unbundled: Evidence from a natural field experiment, Journal of Economic Behavior and Organization 100, 44-63.

Ayres, Ian, Sophie Raseman, and Alice Shih, 2013, Evidence from two large field experiments that peer comparison feedback can reduce residential energy usage, Journal of Law, Economics, and Organization 29, 992-1022.

Banerjee, Abhijit V., 1992, A simple model of herd behavior, Quarterly Journal of Economics 107, 797-817.

Benjamin, Daniel J., James J. Choi, and Geoffrey Fisher, 2010, Religious identity and economic behavior, NBER Working Paper 15925.

Benjamin, Daniel J., James J. Choi, and A. Joshua Strickland, 2010, Social identity and preferences, American Economic Review 100, 1913-1928.

Bernheim, B. Douglas, 1994, A theory of conformity, Journal of Political Economy 102, 841877. 
Bertrand, Marianne, Erzo F. P. Luttmer, and Sendhil Mullainathan, 2000, Network effects and welfare cultures, Quarterly Journal of Economics 115, 1019-1055.

Beshears, John, James J. Choi, David Laibson, and Brigitte C. Madrian, 2008, The importance of default options for retirement saving outcomes: Evidence from the United States, in Stephen J. Kay and Tapen Sinha, eds.: Lessons from Pension Reform in the Americas (Oxford University Press).

Beshears, John, James J. Choi, David Laibson, and Brigitte C. Madrian, 2013, Simplification and saving, Journal of Economic Behavior and Organization 92, 1787-1794.

Beshears, John, James J. Choi, David Laibson, Brigitte C. Madrian, and Gwendolyn Reynolds, 2013, Testimonials do not convert patients from brand to generic medication, American Journal of Managed Care 19, e314-e316.

Besley, Timothy, and Anne Case, 1994, Diffusion as a learning process: Evidence from HYV cotton, Princeton University Research Program in Development Studies Discussion Paper no. 174, Princeton University.

Bhargava, Saurabh, and Dayanand Manoli, 2011, Why are benefits left on the table? Assessing the role of information, complexity, and stigma on take-up with an IRS field experiment, Working Paper.

Bikhchandani, Sushil, David Hirshleifer, and Ivo Welch, 1992, A theory of fads, fashion, custom, and cultural change as informational cascades, Journal of Political Economy 100, 9921026.

Bizjak, John, Michael Lemmon, and Ryan Whitby, 2009, Option backdating and board interlocks, Review of Financial Studies 22, 4821-4847.

Brehm, Jack W., 1966, A Theory of Psychological Reactance (Academic Press, New York).

Brown, Jeffrey R., Zoran Ivkovic, Paul A. Smith, and Scott Weisbenner, 2008, Neighbors matter: Causal community effects and stock market participation, Journal of Finance 63, 15091531.

Cai, Hongbin, Yuyu Chen, and Hanming Fang, 2009, Observational learning: Evidence from a randomized natural field experiment, American Economic Review 99, 864-882.

Card, David, Alexandre Mas, Enrico Moretti, and Emmanuel Saez, 2012, Inequality at work: The effect of peer salaries on job satisfaction, American Economic Review 102, 2981-3003.

Carlin, Bruce Ian, Simon Gervais, and Gustavo Manso, 2013, Libertarian paternalism, information sharing, and financial decision-making, Review of Financial Studies 26, 2204-2228. 
Carrell, Scott E., Bruce I. Sacerdote, and James E. West, 2013, From natural variation to optimal policy? The Lucas Critique meets peer effects, Econometrica 81, 855-882.

Case, Anne C., and Lawrence F. Katz, 1991, The company you keep: The effects of family and neighborhood on disadvantaged youths, NBER Working Paper 3705.

Chalmers, John M. R., Woodrow T. Johnson, and Jonathan Reuter, forthcoming, The effect of pension design on employer costs and employee retirement choices: Evidence from Oregon, Journal of Public Economics.

Chen, Yan, F. Maxwell Harper, Joseph Konstan, and Sherry Xin Li, 2010, Social comparisons and contributions to online communities: A field experiment on MovieLens, American Economic Review 100, 1358-1398.

Choi, James J., David Laibson, and Brigitte C. Madrian, 2009, Reducing the complexity costs of 401(k) participation through Quick Enrollment, in David A. Wise, ed.: Developments in the Economics of Aging (University of Chicago Press).

Choi, James J., David Laibson, Brigitte C. Madrian, and Andrew Metrick, 2002, Defined contribution pensions: Plan rules, participant decisions, and the path of least resistance, in James Poterba, ed.: Tax Policy and the Economy (MIT Press).

Choi, James J., David Laibson, Brigitte C. Madrian, and Andrew Metrick, 2004, For better or for worse: Default effects and 401(k) savings behavior, in David A. Wise, ed.: Perspectives on the Economics of Aging (University of Chicago Press).

Cialdini, Robert B., Linda J. Demaine, Brad J. Sagarin, Daniel W. Barrett, Kelton Rhoads, and Patricia L. Winter, 2006, Managing social norms for persuasive impact, Social Influence 1, 3-15.

Cialdini, Robert B., Raymond R. Reno, and Carl A. Kallgren, 1990, A focus theory of normative conduct: Recycling the concept of norms to reduce littering in public places, Journal of Personality and Social Psychology 58, 1015-1026.

Clee, Mona A., and Robert A. Wicklund, 1980, Consumer behavior and psychological reactance, Journal of Consumer Research 6, 389-405.

Costa, Dora L., and Matthew E. Kahn, 2013, Energy conservation 'nudges' and environmentalist ideology: Evidence from a randomized residential electricity field experiment, Journal of the European Economic Association 11, 680-702.

Duflo, Esther, and Emmanuel Saez, 2002, Participation and investment decisions in a retirement plan: The influence of colleagues' choices, Journal of Public Economics 85, 121-148.

Duflo, Esther, and Emmanuel Saez, 2003, The role of information and social interactions in retirement plan decisions: Evidence from a randomized experiment, Quarterly Journal of Economics 118, 815-842. 
Ellison, Glenn, and Drew Fudenberg, 1993, Rules of thumb for social learning, Journal of Political Economy 101, 612-643.

Erez, Miriam, and Isaac Zidon, 1984, Effect of goal acceptance on the relationship of goal difficulty to performance, Journal of Applied Psychology 69, 69-78.

Fellner, Gerlinde, Rupert Sausgruber, and Christian Traxler, 2013, Testing enforcement strategies in the field: Threat, moral appeal and social information, Journal of the European Economic Association 11, 634-660.

Festinger, Leon, 1954, A theory of social comparison processes, Human Relations 7, 117-140.

Foster, Andrew D., and Mark R. Rosenzweig, 1995, Learning by doing and learning from others: Human capital and technical change in agriculture, Journal of Political Economy 103, 11761209.

Frey, Bruno S., and Stephan Meier, 2004, Social comparisons and pro-social behavior: Testing 'conditional cooperation' in a field experiment, American Economic Review 94, 1717-1722.

Gerber, Alan S., Donald P. Green, and Christopher W. Larimer, 2008, Social pressure and voter turnout: Evidence from a large-scale field experiment, American Political Science Review 102, $33-48$.

Gerber, Alan S., and Todd Rogers, 2009, Descriptive social norms and motivation to vote: Everybody's voting and so should you, Journal of Politics 71, 178-191.

Glaeser, Edward L., Bruce Sacerdote, and José A. Scheinkman, 1996, Crime and social interactions, Quarterly Journal of Economics 111, 507-548.

Glaeser, Edward L., and José A. Scheinkman, 2003, Non-market interactions, in Mathias Dewatripont, Lars Peter Hansen, and Stephen J. Turnovsky, eds.: Advances in Economics and Econometrics: Theory and Applications, Eighth World Congress, Volume I (Cambridge University Press).

Goldstein, Noah J., Robert B. Cialdini, and Vladas Griskevicius, 2008, A room with a viewpoint: Using social norms to motivate environmental conservation in hotels, Journal of Consumer Research 35, 472-482.

Gollwitzer, Peter M., 1999, Implementation intentions: Strong effects of simple plans, American Psychologist 54, 493-503.

Grinblatt, Mark, Matti Keloharju, and Seppo Ikäheimo, 2008, Social influence and consumption: Evidence from the automobile purchases of neighbors, Review of Economics and Statistics 90, 735-753. 
Harrison, Glenn W., and John A. List, 2004, Field experiments, Journal of Economic Literature 42, 1009-1055.

Heath, Chip, Richard P. Larrick, and George Wu, 1999, Goals as reference points, Cognitive Psychology 38, 79-109.

Hershey, John C., David A. Asch, Thi Thumasathit, Jacqueline Meszaros, and Victor V. Waters, 1994, The roles of altruism, free riding, and bandwagoning in vaccination decisions, Organizational Behavior and Human Decision Processes 59, 177-187.

Hirshleifer, David, and Siew Hong Teoh, 2003, Herd behavior and cascading in capital markets: A review and synthesis, European Financial Management 9, 25-66.

Hong, Harrison, Jeffrey D. Kubik, and Jeremy C. Stein, 2004, Social interaction and stockmarket participation, Journal of Finance 59, 137-163.

Jones, Edward E., and Harold B. Gerard, 1967, Fundamentals of Social Psychology (John Wiley and Sons, Inc., New York).

Kallgren, Carl A., Raymond R. Reno, and Robert B. Cialdini, 2000, A focus theory of normative conduct: When norms do and do not affect behavior, Personality and Social Psychology Bulletin 26, 1002-1012.

Kuhn, Peter, Peter Kooreman, Adriaan Soetevent, and Arie Kapteyn, 2011, The effects of lottery prizes on winners and their neighbors: Evidence from the Dutch postcode lottery, American Economic Review 101, 2226-2247.

Lee, Thomas W., Edwin A. Locke, and Soo H. Phan, 1997, Explaining the assigned goalincentive interaction: The role of self-efficacy and personal goals, Journal of Management 23, 541-559.

Lerner, Josh, and Ulrike Malmendier, 2013, With a little help from my (random) friends: Success and failure in post-business school entrepreneurship, Review of Financial Studies 26, 2411-2452.

Locke, Edwin A., and Gary P. Latham, 2002, Building a practically useful theory of goal setting and task motivation: A 35-year odyssey, American Psychologist 57, 705-717.

Locke, Edwin A., Karyll N. Shaw, Lise M. Saari, and Gary P. Latham, 1981, Goal setting and task performance: 1969-1980, Psychological Bulletin 90, 125-152.

Madrian, Brigitte C., and Dennis F. Shea, 2001, The power of suggestion: Inertia in 401(k) participation and savings behavior, Quarterly Journal of Economics 116, 1149-1187.

Manski, Charles F., 1993, Identification of endogenous social effects: The reflection problem, Review of Economic Studies 60, 531-542. 
Manski, Charles F., 2000, Economic analysis of social interactions, Journal of Economic Perspectives 14(3), 115-136.

Mento, Anthony J., Robert P. Steel, and Ronald J. Karren, 1987, A meta-analytic study of the effects of goal setting on task performance: 1966-1984, Organizational Behavior and Human Decision Processes 39, 52-83.

Mitchell, Olivia S., and Annamaria Lusardi, 2011, Financial Literacy: Implications for Retirement Security and the Financial Marketplace (Oxford University Press, Oxford).

Motowidlo, Stephan J., Virginia Loehr, and Marvin D. Dunnette, 1978, A laboratory study of the effects of goal specificity on the relationship between probability of success and performance, Journal of Applied Psychology 63, 172-179.

Mowen, John C., R. Dennis Middlemist, and David Luther, 1981, Joint effects of assigned goal level and incentive structure on task performance: A laboratory study, Journal of Applied Psychology 66, 598-603.

Munshi, Kaivan, 2004, Social learning in a heterogeneous population: Technology diffusion in the Indian Green Revolution, Journal of Development Economics 73, 185-213.

Munshi, Kaivan, and Jacques Myaux, 2006, Social norms and the fertility transition, Journal of Development Economics 80, 1-38.

Narayanan, Sridhar, and Harikesh S. Nair, 2013, Estimating causal installed-base effects: A biascorrection approach, Journal of Marketing Research 50, 70-94.

Price, John, Leon Sloman, Russell Gardner, Jr., Paul Gilert, and Peter Rohde, 1994, The social competition hypothesis of depression, British Journal of Psychiatry 164, 309-315.

Ringold, Debra Jones, 2002, Boomerang effects in response to public health interventions: Some unintended consequences in the alcoholic beverage market, Journal of Consumer Policy 25, 2763.

Sacerdote, Bruce, 2001, Peer effects with random assignment: Results for Dartmouth roommates, Quarterly Journal of Economics 116, 681-704.

Salganik, Matthew J., Peter Sheridan Dodds, and Duncan J. Watts, 2006, Experimental study of inequality and unpredictability in an artificial cultural market, Science 311, 854-856.

Schultz, P. Wesley, Jessica M. Nolan, Robert B. Cialdini, Noah J. Goldstein, and Vladas Griskevicius, 2007, The constructive, destructive, and reconstructive power of social norms, Psychological Science 18, 429-434.

Shue, Kelly, 2013, Executive networks and firm policies: Evidence from the random assignment of MBA peers, Review of Financial Studies 26, 1401-1442. 
Sloman, Leon, Paul Gilbert, and Gary Hasey, 2003, Evolved mechanisms in depression: the role and interaction of attachment and social rank in depression, Journal of Affective Disorders 74, 107-121.

Sorensen, Alan T., 2006, Social learning and health plan choice, RAND Journal of Economics 37, 929-945.

Suls, Jerry M., and Ladd Wheeler, 2000, Handbook of Social Comparison: Theory and Research (Kluwer Academic Publishers, New York).

Wechsler, Henry, Toben F. Nelson, Jae Eun Lee, Mark Seibring, Catherine Lewis, and Richard P. Keeling, 2003, Perception and reality: A national evaluation of social norms marketing interventions to reduce college students' heavy alcohol use, Journal of Studies on Alcohol 64, 484-494. 


\section{Appendix A: Sample Quick Enrollment Letter with No Peer Information}

\section{Stop Waiting. .. Start Saving!}

Participate in the company retirement plan to

plan for your future and get company matching money. Simply check Yes on the attached response card, and return it by August 22, 2008 to enroll in the plan

Yes, you will:

Start contributing $6 \%$ of your eligible pay to the plan By doing so, you will receive the company match, which is 50 cents on the dollar on the first $6 \%$ of your eligible pay you contribute on a before-tax basis.

Invest in the company Target Retirement 2045 Fund. The asset mix of the company Target Retirement 2045 fund is designed for someone who may retire in 2045 and will become more conservative as you approach retirement.

Once you enroll in the plan you have the freedom to change your contribution rate and investment options at any time. Visit

URL
more information.
Don't turn down the company match! Check Yes below and return the card in the
enclosed postage-paid envelope to enroll today.

\section{Your response is needed by August 22, 2008!}

Yes! I want to receive the full company match! Enroll me in the plan today.

- By making this election, I will automatically begin contributing $6 \%$ of my eligible pay on a before-tax basis, which qualifies me for the full company match. ${ }^{*}$ My contribution will be invested in the company Target Retirement 2045 Fund, based on my age and estimated retirement date. $^{\star \star}$

- I also know that I can change my elections at any time by visiting Your Benefits Resources ${ }^{\mathrm{TM}}$ at

URL _ or by calling phone number 


\section{Appendix B: Sample Quick Enrollment Letter with Peer Information}

\section{Stop Waiting. .. Start Saving!}

Partcipate in the company retirement plan

plan for your future and get company matching money. Simply check Yes on the attached response card, and return it by August 22, 2008 to enroll in the plan

Join the $87 \%$ of $25-29$ year old employees at company who are already enrolled in the plan.

By checking Yes, you will:

Start contributing $6 \%$ of your eligible pay to the plan By doing so, you will receive the company match, which is 50 cents on the dollar on the first $6 \%$ of your eligible pay you contribute on a before-tax basis.

Invest in the conpany Target Retirement 2045 Fund. The asset mix of the company Target Retirement 2045 fund is designed for someone who may retire in 2045 and will become more conservative as you approach retirement.

Once you enroll in the plan you have the freedom to change your contribution rate and investment options at any time. Visit URL more information.

Don't turn down the company match! Check Yes below and return the card in the enclosed postage-paid envelope to enroll today.

\section{Your response is needed by August 22, 2008!}

Yes! I want to receive the full company match! Enroll me in the plan today.

- By making this election, I will automatically begin contributing $6 \%$ of my eligible pay on a betore-tax basis, which qualifies me for the full company match. ${ }^{\star}$ My contribution will be invested in the company Target Retirement 2045 Fund, based on my age and estimated retirement date."

- I also know that I can change my elections at any time by visiting Your Benefits Resources ${ }^{\mathrm{TM}}$ at URL 


\section{Appendix C: Sample Easy Escalation Letter with No Peer Information}

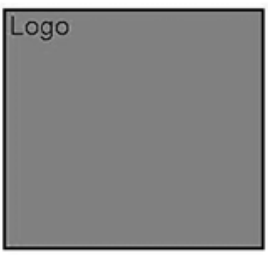

\section{Stop Missing Out!}

Because you're currently contributing below the full match level
to the company
\begin{tabular}{|c|c|}
\hline plan \\
you're leaving money on the table.
\end{tabular}

Simply check Yes on the attached response card, and return it by August 22, 2008 to increase your contribution rate and start receiving the maximum plan match available to you.

Every day you

wait, you're

missing out

on the matching

contributions

available to you.

By checking Yes, you will:

Start contributing $6 \%$ of your eligible pay to the plan on a before-tax basis.

Receive the full company match, which is 50 cents on the dollar on the first

$6 \%$ of your eligible pay you contribute on a before-tax basis.

That's money

you can't

get back.

Your contributions will be invested according to your current investment elections.

As always, you have the freedom to change your contribution rate and investment

options at any time. Visit URL or call

phone number for more information.

Don't turn down free money! Check Yes below and return the card in the enclosed postage-paid envelope to start receiving the full pan match.

\section{Your response is needed by August 22, 2008!}

$\square$ Yes! I want to receive the full company match. Increase my contribution rate today.

- By making this election, I will automatically begin contribuing $6 \%$ of my eligible pay on a before-tax basis, which qualifies me for the full company match. ${ }^{\star}$ My after-tax contribution (if any) will remain the same. My contributions will be invested according to my current investment election. ${ }^{\star \star}$

- I also know that I can change my elections at any time by visiting Your Benefits Resources ${ }^{\mathrm{TM}}$ at URL 


\section{Appendix D: Sample Easy Escalation Letter with Peer Information}

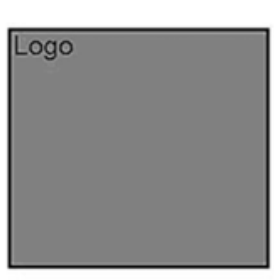

\section{Stop Missing Out!}

Because you're currently contributing below the full match level
to the comoany retirement
\begin{tabular}{|c|}
\hline plan \\
\hline
\end{tabular} you're leaving money on the table.

Simply check Yes on the attached response card, and return it by August 22, 2008 to increase your contribution rate and start receiving the maximum plan match available to you.

Every day you wait, you're missing out on the matching contributions available to you.

Join the $76 \%$ of $20-29$ year old plan participants at company who are already contributing at least $6 \%$ to the plan

By checking Yes, you will:

Start contributing $6 \%$ of your eligible pay to the plan on a before-tax basis.

Receive the full company match, which is 50 cents on the dollar on the first $6 \%$ of your eligible pay you contribute on a before-tax basis.

That's money you can't get back.

Your contributions will be invested according to your current investment elections.

As always, you have the freedom to change your contribution rate and investment options at any time. Visit URL or call phone number for more information.

Don't turn down free money! Check Yes below and return the card in the enclosed postage-paid envelope to start receiving the full pan match.

\section{Your response is needed by August 22, 2008!}

Yes! I want to receive the full company match. Increase my contribution rate today.

- By making this election, I will automatically begin contributing $6 \%$ of my eligible pay on a before-tax basis, which qualifies me for the full company match. ${ }^{\star}$ My after-tax contribution (if any) will remain the same. My contributions will be invested according to my current investment election."

- I also know that I can change my elections at any time by visiting Your Benefits Resources ${ }^{\mathrm{TM}}$ at URL 
Table I: Features of the Four Subpopulations in the Experiment

This table summarizes the key features of the four subpopulations that were targeted in the field experiment.

\begin{tabular}{|c|c|c|c|c|}
\hline \multirow[b]{3}{*}{$\begin{array}{l}\text { Union } \\
\text { membership }\end{array}$} & \multicolumn{2}{|c|}{ Quick Enrollment recipients } & \multicolumn{2}{|c|}{ Easy Escalation recipients } \\
\hline & $\begin{array}{l}0 \% \text { contribution } \\
\text { rate default }\end{array}$ & $\begin{array}{l}6 \% \text { contribution } \\
\text { rate default }\end{array}$ & $\begin{array}{l}0 \% \text { contribution } \\
\text { rate default }\end{array}$ & $\begin{array}{l}6 \% \text { contribution } \\
\text { rate default }\end{array}$ \\
\hline & Yes & No & Yes & No \\
\hline $\begin{array}{l}\text { Savings plan } \\
\text { enrollment } \\
\text { mechanism }\end{array}$ & Opt-in & $\begin{array}{c}\text { Opt-out } \\
\text { (automatic } \\
\text { enrollment) }\end{array}$ & Opt-in & $\begin{array}{l}\text { Opt-out } \\
\text { (automatic } \\
\text { enrollment) }\end{array}$ \\
\hline $\begin{array}{l}\text { Savings plan } \\
\text { participation } \\
\text { status prior to } \\
\text { experiment }\end{array}$ & Non-participant & Non-participant & Participant & Participant \\
\hline $\begin{array}{l}\text { Savings plan } \\
\text { contribution rate } \\
\text { prior to } \\
\text { experiment }\end{array}$ & $0 \%$ & $0 \%$ & $\begin{array}{l}\text { Less than } 6 \% \\
\text { and less than } \\
\text { their } 401(\mathrm{k}) \\
\text { match threshold }\end{array}$ & $\begin{array}{l}\text { Less than } 6 \% \\
\text { (which is their } \\
401(\mathrm{k}) \text { match } \\
\text { threshold) }\end{array}$ \\
\hline $\begin{array}{l}\text { Savings plan } \\
\text { decision prior to } \\
\text { experiment }\end{array}$ & $\begin{array}{c}\text { Passively } \\
\text { accepted default }\end{array}$ & $\begin{array}{l}\text { Actively opted } \\
\text { out of plan }\end{array}$ & $\begin{array}{l}\text { Actively chose } \\
\text { contribution rate }\end{array}$ & $\begin{array}{l}\text { Actively chose } \\
\text { contribution rate }\end{array}$ \\
\hline
\end{tabular}


Table II: Employer Match Formulas

This table describes the employer match formulas that applied to different groups of employees at the firm.

\begin{tabular}{|c|c|c|c|}
\hline \multirow[b]{3}{*}{ Match A } & \multirow[b]{2}{*}{ Match formula for before-tax contributions } & \multicolumn{2}{|c|}{$\begin{array}{l}\text { Number of employees included in } \\
\text { the mailing with this match }\end{array}$} \\
\hline & & Union & Non-union \\
\hline & $\begin{array}{l}100 \% \text { on the first } 1 \% \text { of pay contributed } \\
50 \% \text { on the next } 5 \% \text { of pay contributed }\end{array}$ & 0 & 3,158 \\
\hline Match B & $\begin{array}{l}\text { The minimum of } \$ 325 \text { or } 50 \% \text { on the first } \\
2 \% \text { of pay contributed }\end{array}$ & 126 & 0 \\
\hline Match C & $\begin{array}{l}100 \% \text { on the first } 2 \% \text { of pay contributed } \\
50 \% \text { on the next } 2 \% \text { of pay contributed } \\
25 \% \text { on the next } 4 \% \text { of pay contributed }\end{array}$ & 1,114 & 0 \\
\hline Match D & $\begin{array}{l}100 \% \text { on the first } 2 \% \text { of pay contributed } \\
50 \% \text { on the next } 2 \% \text { of pay contributed } \\
25 \% \text { on the next } 2 \% \text { of pay contributed }\end{array}$ & 261 & 0 \\
\hline Match E & $50 \%$ on the first $4 \%$ of pay contributed & 135 & 0 \\
\hline Match F & $50 \%$ on the first $6 \%$ of pay contributed & 149 & 0 \\
\hline Match $\mathrm{G}^{\dagger}$ & None & 0 & 0 \\
\hline
\end{tabular}

${ }^{\dagger}$ This group was not included in the intervention. 


\section{Table III: Peer Information Values}

This table lists the peer information values in the mailings sent to employees in the peer information treatments. Employees not participating in the savings plan were sent the participation rate of employees in either their 5-year or 10-year age bracket (first column). Participating employees with before-tax contribution rates below both their match threshold and $6 \%$ were sent the fraction of participants in either their 5-year or 10-year age bracket whose before-tax contribution rate was at least $6 \%$ (third column).

\begin{tabular}{|c|c|c|c|c|}
\hline & $\begin{array}{c}\text { Savings plan } \\
\text { participation } \\
\text { rate } \\
\end{array}$ & $\begin{array}{c}\text { \# of employees } \\
\text { sent } \\
\text { participation } \\
\text { rate } \\
\end{array}$ & $\begin{array}{l}\text { Fraction of } \\
\text { participants } \\
\text { contributing } \\
\geq 6 \% \text { of pay } \\
\end{array}$ & $\begin{array}{c}\# \text { of } \\
\text { employees } \\
\text { sent } \geq 6 \% \\
\text { contributor } \\
\text { fraction }\end{array}$ \\
\hline \multicolumn{5}{|c|}{ 5-year age brackets } \\
\hline $20-24$ & $77 \%$ & 61 & $79 \%$ & 57 \\
\hline $25-29$ & $87 \%$ & 72 & $74 \%$ & 155 \\
\hline $30-34$ & $90 \%$ & 45 & $72 \%$ & 161 \\
\hline $35-39$ & $90 \%$ & 61 & $72 \%$ & 162 \\
\hline $40-44$ & $92 \%$ & 55 & $73 \%$ & 166 \\
\hline $45-49$ & $93 \%$ & 41 & $75 \%$ & 172 \\
\hline $50-54$ & $91 \%$ & 56 & $77 \%$ & 142 \\
\hline $55-59$ & $90 \%$ & 44 & $78 \%$ & 102 \\
\hline $60-64$ & $88 \%$ & 35 & $79 \%$ & 47 \\
\hline $65-69$ & $87 \%$ & 7 & $81 \%$ & 7 \\
\hline \multicolumn{5}{|c|}{ 10-year age brackets } \\
\hline $20-29$ & $83 \%$ & 135 & $76 \%$ & 202 \\
\hline $30-39$ & $90 \%$ & 104 & $72 \%$ & 331 \\
\hline $40-49$ & $92 \%$ & 97 & $74 \%$ & 339 \\
\hline $50-59$ & $91 \%$ & 109 & $78 \%$ & 240 \\
\hline $60-69$ & $88 \%$ & 38 & $79 \%$ & 55 \\
\hline
\end{tabular}


Table IV: Sample Characteristics

This table summarizes the characteristics of Quick Enrollment recipients (Panel A) and Easy Escalation recipients (Panel B). Employees are grouped by their contribution rate default and the type of peer information they received in their mailing. Salary data are missing for some employees in the sample. These employees are excluded from the regression analyses in subsequent tables.

\begin{tabular}{|c|c|c|c|c|c|c|}
\hline \multicolumn{7}{|c|}{$\begin{array}{l}\text { Panel A: Quick Enrollment recipients } \\
\text { (non-participants in the savings plan) }\end{array}$} \\
\hline & \multicolumn{3}{|c|}{$0 \%$ contribution rate default } & \multicolumn{3}{|c|}{$6 \%$ contribution rate default } \\
\hline & $\begin{array}{l}\text { No peer } \\
\text { information }\end{array}$ & $\begin{array}{c}\text { 5-yr. age } \\
\text { bracket peer } \\
\text { information }\end{array}$ & $\begin{array}{c}\text { 10-yr. age } \\
\text { bracket peer } \\
\text { information }\end{array}$ & $\begin{array}{c}\text { No peer } \\
\text { information }\end{array}$ & $\begin{array}{c}\text { 5-yr. age } \\
\text { bracket peer } \\
\text { information }\end{array}$ & $\begin{array}{l}\text { 10-yr. age } \\
\text { bracket peer } \\
\text { information }\end{array}$ \\
\hline Percent male & 69.1 & 66.0 & 61.6 & 77.2 & 75.4 & 75.4 \\
\hline Age & & & & & & \\
\hline $\begin{array}{l}\text { Mean } \\
\text { (Std. dev.) }\end{array}$ & $\begin{array}{c}41.0 \\
(13.4)\end{array}$ & $\begin{array}{c}40.7 \\
(13.4)\end{array}$ & $\begin{array}{c}41.0 \\
(13.4)\end{array}$ & $\begin{array}{c}40.4 \\
(11.4)\end{array}$ & $\begin{array}{c}41.2 \\
(11.6)\end{array}$ & $\begin{array}{c}41.3 \\
(12.2)\end{array}$ \\
\hline $\begin{array}{l}\text { Tenure (years) } \\
\text { Mean } \\
\text { (Std. dev.) }\end{array}$ & $\begin{array}{c}9.4 \\
(12.0)\end{array}$ & $\begin{array}{c}9.5 \\
(12.1)\end{array}$ & $\begin{array}{c}9.0 \\
(12.1)\end{array}$ & $\begin{array}{c}7.2 \\
(9.3)\end{array}$ & $\begin{array}{c}7.5 \\
(9.5)\end{array}$ & $\begin{array}{c}7.8 \\
(8.4)\end{array}$ \\
\hline $\begin{array}{l}\text { Annual salary (\$1000 } \\
\text { Mean } \\
\text { (Std. dev.) }\end{array}$ & $\begin{array}{c}38.3 \\
(16.7)\end{array}$ & $\begin{array}{c}38.1 \\
(15.1)\end{array}$ & $\begin{array}{c}39.0 \\
(18.9)\end{array}$ & $\begin{array}{c}46.3 \\
(22.3)\end{array}$ & $\begin{array}{c}46.2 \\
(23.9)\end{array}$ & $\begin{array}{c}45.1 \\
(21.5)\end{array}$ \\
\hline Sample size & $N=343$ & $N=347$ & $N=349$ & $N=136$ & $N=130$ & $N=134$ \\
\hline \# missing salary data & 6 & 2 & 7 & 1 & 0 & 0 \\
\hline
\end{tabular}


Panel B: Easy Escalation recipients

(plan participants with initial before-tax contribution rate $<\min \{$ match threshold, $6 \%\}$ )

\begin{tabular}{|c|c|c|c|c|c|c|}
\hline \multirow[b]{3}{*}{ Percent male } & \multicolumn{3}{|c|}{$0 \%$ contribution rate default } & \multicolumn{3}{|c|}{$6 \%$ contribution rate default } \\
\hline & $\begin{array}{c}\text { No peer } \\
\text { information }\end{array}$ & $\begin{array}{c}\text { 5-yr. age } \\
\text { bracket peer } \\
\text { information }\end{array}$ & $\begin{array}{l}\text { 10-yr. age } \\
\text { bracket peer } \\
\text { information }\end{array}$ & $\begin{array}{c}\text { No peer } \\
\text { information }\end{array}$ & $\begin{array}{c}\text { 5-yr. age } \\
\text { bracket peer } \\
\text { information }\end{array}$ & $\begin{array}{l}\text { 10-yr. age } \\
\text { bracket peer } \\
\text { information }\end{array}$ \\
\hline & 61.3 & 51.8 & 52.0 & 67.7 & 67.6 & 69.5 \\
\hline $\begin{array}{l}\text { Age } \\
\text { Mean } \\
\text { (Std. dev.) }\end{array}$ & $\begin{array}{c}39.9 \\
(11.7)\end{array}$ & $\begin{array}{c}40.8 \\
(11.8)\end{array}$ & $\begin{array}{c}41.1 \\
(11.9)\end{array}$ & $\begin{array}{c}41.8 \\
(10.6)\end{array}$ & $\begin{array}{c}42.0 \\
(10.7)\end{array}$ & $\begin{array}{c}42.0 \\
(10.5)\end{array}$ \\
\hline $\begin{array}{l}\text { Tenure (years) } \\
\text { Mean } \\
\text { (Std. dev.) }\end{array}$ & $\begin{array}{c}11.4 \\
(10.1)\end{array}$ & $\begin{array}{l}10.6 \\
(9.8)\end{array}$ & $\begin{array}{l}10.5 \\
(10.6)\end{array}$ & $\begin{array}{l}10.7 \\
(10.2)\end{array}$ & $\begin{array}{l}10.5 \\
(9.6)\end{array}$ & $\begin{array}{l}11.1 \\
(9.9)\end{array}$ \\
\hline $\begin{array}{l}\text { Annual salary }(\$ 1000 \\
\text { Mean } \\
\text { (Std. dev.) }\end{array}$ & $\begin{array}{c}43.8 \\
(16.2)\end{array}$ & $\begin{array}{c}42.0 \\
(13.3)\end{array}$ & $\begin{array}{c}41.1 \\
(14.2)\end{array}$ & $\begin{array}{c}57.4 \\
(30.3)\end{array}$ & $\begin{array}{c}56.1 \\
(24.8)\end{array}$ & $\begin{array}{c}58.3 \\
(28.3)\end{array}$ \\
\hline $\begin{array}{l}\text { Before-tax contrib. rat } \\
\text { Mean } \\
\text { (Std. dev.) }\end{array}$ & $\begin{array}{c}2.5 \\
(1.8)\end{array}$ & $\begin{array}{c}2.5 \\
(1.8)\end{array}$ & $\begin{array}{c}2.6 \\
(1.8)\end{array}$ & $\begin{array}{c}1.9 \\
(1.7)\end{array}$ & $\begin{array}{c}1.8 \\
(1.8)\end{array}$ & $\begin{array}{c}1.8 \\
(1.8)\end{array}$ \\
\hline Sample size & $N=235$ & $N=255$ & $N=256$ & $N=931$ & $N=916$ & $N=911$ \\
\hline \# missing salary data & 0 & 0 & 0 & 0 & 2 & 3 \\
\hline
\end{tabular}


Table V: Effect of Receiving Peer Information in Quick Enrollment: Mean Comparisons This table shows the average responses of employees who received Quick Enrollment mailings, reported separately by contribution rate default and treatment condition, and the differences in these average responses across treatment conditions. The responses of interest are enrollment in the savings plan between August 4, 2008 and September 8, 2008 and the before-tax contribution rate change as a percent of income during the same time period. Quick Enrollment recipients in the peer information treatments were shown the plan participation rate of employees in their fiveyear or ten-year age bracket. The first two columns display standard errors from tests of proportions in parentheses, with the standard errors in the last row calculated under the null hypothesis that the two proportions are equal. The last two columns display standard errors robust to heteroskedasticity in parentheses. ${ }^{*},{ }^{* *}$, and $* * *$ in the last row indicate statistical significance at the $10 \%, 5 \%$, and $1 \%$ levels, respectively.

\begin{tabular}{|c|c|c|c|c|}
\hline \multirow[b]{3}{*}{ (1) No peer info } & \multicolumn{2}{|c|}{$\begin{array}{l}\text { Fraction who enrolled in } \\
\text { savings plan }\end{array}$} & \multicolumn{2}{|c|}{$\begin{array}{c}\text { Average before-tax } \\
\text { contribution rate change }\end{array}$} \\
\hline & $0 \%$ default & $6 \%$ default & $0 \%$ default & $6 \%$ default \\
\hline & $\begin{array}{l}9.9 \% \\
(1.6)\end{array}$ & $\begin{array}{c}0.7 \% \\
(0.7)\end{array}$ & $\begin{array}{l}0.58 \% \\
(0.10)\end{array}$ & $\begin{array}{l}0.04 \% \\
(0.04)\end{array}$ \\
\hline (2) 5-year age bracket info & $\begin{array}{l}6.6 \% \\
(1.3)\end{array}$ & $\begin{array}{l}2.3 \% \\
(1.3)\end{array}$ & $\begin{array}{c}0.40 \% \\
(0.08)\end{array}$ & $\begin{array}{l}0.14 \% \\
(0.08)\end{array}$ \\
\hline (3) 10-year age bracket info & $\begin{array}{l}6.0 \% \\
(1.3)\end{array}$ & $\begin{array}{l}3.0 \% \\
(1.5)\end{array}$ & $\begin{array}{l}0.36 \% \\
(0.08)\end{array}$ & $\begin{array}{l}0.16 \% \\
(0.08)\end{array}$ \\
\hline (4) Combined 5-year and 10-year & $\begin{array}{l}6.3 \% \\
(0.9)\end{array}$ & $\begin{array}{l}2.7 \% \\
(1.0)\end{array}$ & $\begin{array}{c}0.38 \% \\
(0.06)\end{array}$ & $\begin{array}{c}0.15 \% \\
(0.06)\end{array}$ \\
\hline Difference: $(4)-(1)$ & $\begin{array}{l}-3.6 \% * * \\
(1.7)\end{array}$ & $\begin{array}{l}1.9 \% \\
(1.5)\end{array}$ & $\begin{array}{l}-0.20 \% * \\
(0.11)\end{array}$ & $\begin{array}{l}0.10 \% \\
(0.07)\end{array}$ \\
\hline
\end{tabular}


Table VI: Effect of Receiving Peer Information in Quick Enrollment: Regression Analysis This table reports the results of ordinary least-squares regressions where the dependent variable is either a dummy for enrolling in the savings plan between August 4, 2008 and September 8, 2008 or the before-tax contribution rate change during the same time period. The sample is Quick Enrollment recipients who have a $0 \%$ contribution rate default (columns 1 and 3 ) or a 6\% contribution rate default (columns 2 and 4). The linear spline in recipient age has knot points at $22.5,27.5,32.5, \ldots$, and 67.5. All regressions include a constant. Standard errors robust to heteroskedasticity are in parentheses. $*, * *$, and $* * *$ indicate statistical significance at the $10 \%$, $5 \%$, and $1 \%$ levels, respectively.

\begin{tabular}{|c|c|c|c|c|}
\hline \multirow[b]{3}{*}{$\begin{array}{l}\text { Received peer info } \\
\text { dummy }\end{array}$} & \multicolumn{2}{|c|}{$\begin{array}{c}\text { Dependent variable: } \\
\text { Enrolled in savings plan }\end{array}$} & \multicolumn{2}{|c|}{$\begin{array}{l}\text { Dependent variable: } \\
\text { Before-tax contribution rate change }\end{array}$} \\
\hline & $0 \%$ default & $6 \%$ default & $0 \%$ default & $6 \%$ default \\
\hline & $\begin{array}{l}-0.040^{* *} \\
(0.019)\end{array}$ & $\begin{array}{c}0.019 \\
(0.014)\end{array}$ & $\begin{array}{l}-0.221^{* *} \\
(0.112)\end{array}$ & $\begin{array}{c}0.099 \\
(0.078)\end{array}$ \\
\hline Male dummy & $\begin{array}{l}-0.013 \\
(0.020)\end{array}$ & $\begin{array}{l}-0.031 \\
(0.021)\end{array}$ & $\begin{array}{l}-0.044 \\
(0.116)\end{array}$ & $\begin{array}{l}-0.154 \\
(0.113)\end{array}$ \\
\hline $\log ($ Tenure $)$ & $\begin{array}{l}-0.025 * * * \\
(0.008)\end{array}$ & $\begin{array}{l}-0.010 \\
(0.006)\end{array}$ & $\begin{array}{l}-0.146 * * * \\
(0.047)\end{array}$ & $\begin{array}{l}-0.054 \\
(0.035)\end{array}$ \\
\hline $\log ($ Salary) & $\begin{array}{c}0.007 \\
(0.021)\end{array}$ & $\begin{array}{r}0.038^{*} \\
(0.024)\end{array}$ & $\begin{array}{c}0.021 \\
(0.129)\end{array}$ & $\begin{array}{r}0.252^{*} \\
(0.136)\end{array}$ \\
\hline Age spline & Yes & Yes & Yes & Yes \\
\hline$R^{2}$ & 0.033 & 0.048 & 0.029 & 0.052 \\
\hline Sample size & $N=1,024$ & $N=399$ & $N=1,024$ & $N=399$ \\
\hline
\end{tabular}


Table VII: Effect of the Peer Information Value Received in Quick Enrollment This table reports the results of ordinary least-squares regressions where the dependent variable is either a dummy for enrolling in the savings plan between August 4, 2008 and September 8, 2008 or the before-tax contribution rate change during the same time period. The sample is Quick Enrollment recipients with a $0 \%$ contribution rate default (columns 1 and 3) or a 6\% contribution rate default (columns 2 and 4 ) who were given peer information. The peer information value was the plan participation rate of coworkers in the recipient's five-year or tenyear age bracket. The linear spline in recipient age has knot points at 22.5, 27.5, 32.5, ..., and 67.5. All regressions include a constant. Standard errors robust to heteroskedasticity are in parentheses. $* * *$, and $* * *$ indicate statistical significance at the $10 \%, 5 \%$, and $1 \%$ levels, respectively.

\begin{tabular}{|c|c|c|c|c|}
\hline \multirow[b]{3}{*}{ Peer info value } & \multicolumn{2}{|c|}{$\begin{array}{l}\text { Dependent variable: } \\
\text { Enrolled in savings plan }\end{array}$} & \multicolumn{2}{|c|}{$\begin{array}{l}\text { Dependent variable: } \\
\text { Before-tax contribution rate change }\end{array}$} \\
\hline & $0 \%$ default & $6 \%$ default & $0 \%$ default & $6 \%$ default \\
\hline & $\begin{array}{l}-1.760 * * \\
(0.731)\end{array}$ & $\begin{array}{r}1.083 * \\
(0.559)\end{array}$ & $\begin{array}{c}-10.663 * * \\
(4.613)\end{array}$ & $\begin{array}{r}5.558^{*} \\
(2.935)\end{array}$ \\
\hline Male dummy & $\begin{array}{c}0.011 \\
(0.022)\end{array}$ & $\begin{array}{l}-0.057^{*} \\
(0.031)\end{array}$ & $\begin{array}{c}0.088 \\
(0.134)\end{array}$ & $\begin{array}{l}-0.293 * \\
(0.166)\end{array}$ \\
\hline $\log ($ Tenure $)$ & $\begin{array}{l}-0.010 \\
(0.009)\end{array}$ & $\begin{array}{l}-0.016^{* *} \\
(0.008)\end{array}$ & $\begin{array}{l}-0.061 \\
(0.053)\end{array}$ & $\begin{array}{l}-0.087 * * \\
(0.044)\end{array}$ \\
\hline $\log ($ Salary $)$ & $\begin{array}{l}-0.022 \\
(0.027)\end{array}$ & $\begin{array}{r}0.062 * \\
(0.034)\end{array}$ & $\begin{array}{l}-0.138 \\
(0.170)\end{array}$ & $\begin{array}{l}0.398^{* *} \\
(0.199)\end{array}$ \\
\hline Age spline & Yes & Yes & Yes & Yes \\
\hline$R^{2}$ & 0.034 & 0.085 & 0.033 & 0.091 \\
\hline Sample size & $N=687$ & $N=264$ & $N=687$ & $N=264$ \\
\hline
\end{tabular}




\section{Table VIII: Effect of the Peer Information Value Received in Quick Enrollment: Sources of Identification}

This table reports the peer information value coefficients from ordinary least-squares regressions analyzing employee responses to Quick Enrollment mailings. The coefficients in each cell come from separate regressions. The sample is recipients of Quick Enrollment mailings that included a peer information value equal to the savings plan participation rate of coworkers in either the recipient's five-year or ten-year age bracket. Depending on the row, the sample is further restricted to employees with a $0 \%$ contribution rate default or a $6 \%$ contribution rate default. The dependent variable is either a dummy for enrolling in the savings plan between August 4, 2008 and September 8, 2008 or the before-tax contribution rate change during the same time period. The column headings indicate the source of variation used to identify the peer information value coefficient. All regressions include controls for gender, log tenure, log salary, and a constant, as in Table VII, as well as a linear spline in recipient age with knot points at 22.5, 27.5, 32.5, .., and 67.5. Additional controls for age are included as indicated in the bottom rows. Standard errors robust to heteroskedasticity are in parentheses. *,**, and *** indicate statistical significance at the $10 \%, 5 \%$, and $1 \%$ levels, respectively.

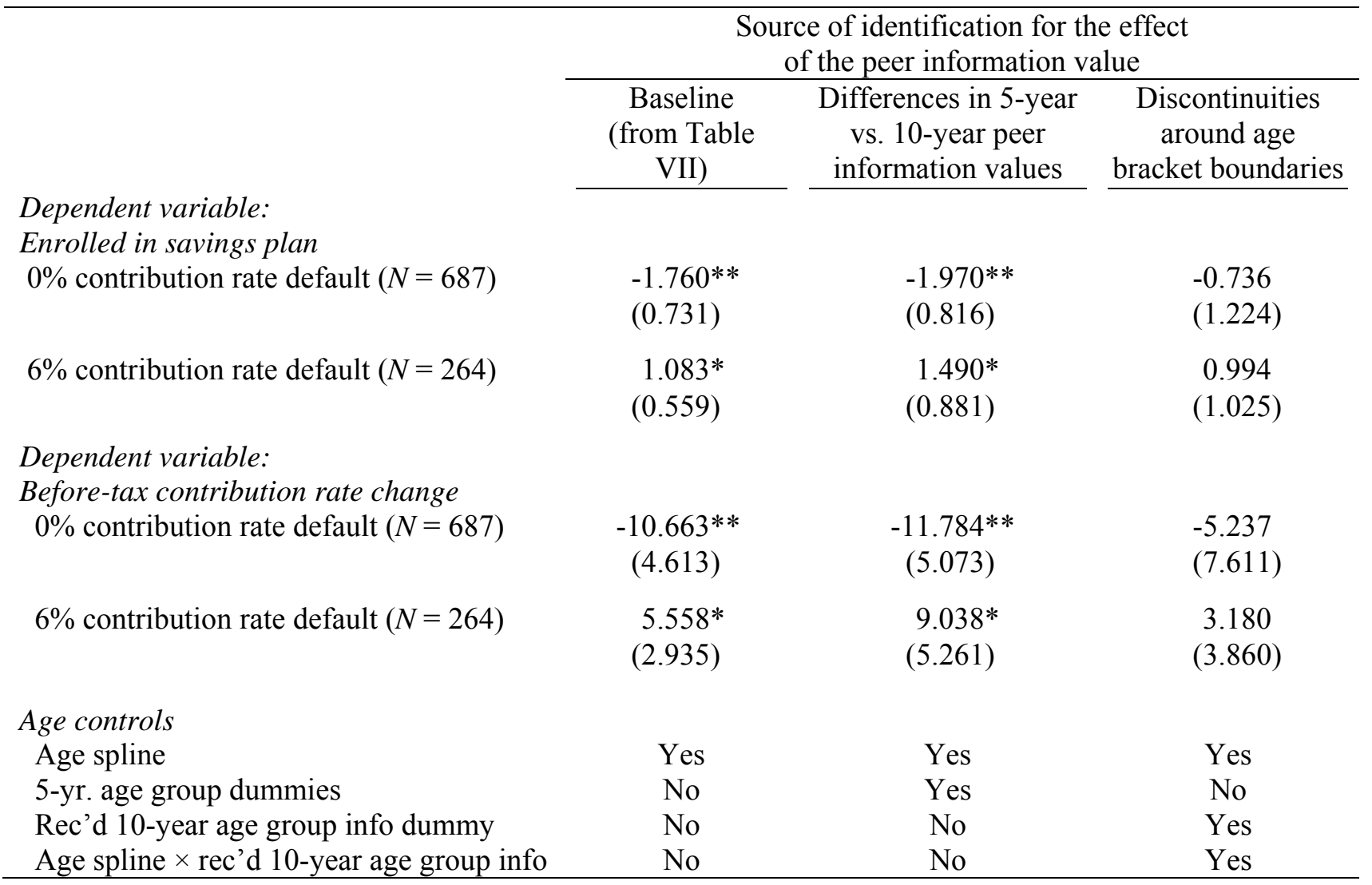




\section{Table IX: Effect of the Peer Information Value Received in Quick Enrollment: Robustness to Different Age Controls}

This table reports the peer information value coefficients from ordinary least-squares regressions analyzing employee responses to Quick Enrollment mailings. The estimated coefficients in each cell come from separate regressions. The sample is recipients of Quick Enrollment mailings that included a peer information value equal to the savings plan participation rate of coworkers in either the recipient's five-year or ten-year age bracket. The sample is further restricted to those with a $0 \%$ contribution rate default (columns 1 and 3 ) or a $6 \%$ contribution rate default (columns 2 and 4). The dependent variable is either a dummy for enrolling in the plan between August 4, 2008 and September 8, 2008 or the before-tax contribution rate change during the same time period. All regressions include controls for gender, log tenure, log salary, and a constant, as in Table VII. The regressions vary in how they control for recipient age: (1) a linear spline in age with knot points at 22.5, 27.5, 32.5, ..., and 67.5 (every five years), which is the baseline; (2) a linear spline in age with knot points at 22.5, 25, 27.5, ..., and 67.5 (every 2.5 years); (3) a linear spline in age with knot points every 5 years and dummies for the target date retirement fund offered, which is dependent on age; (4) a linear spline in age with knot points every five years and controls for the number of years the recipient is from the age group mean (linear and squared terms); or (5) a linear spline in age with knot points every five years and controls for the recipient's percentile rank in the age group (linear and squared terms). Standard errors robust to heteroskedasticity are in parentheses. $*, * *$, and $* * *$ indicate statistical significance at the $10 \%$, $5 \%$, and $1 \%$ levels, respectively.

\begin{tabular}{|c|c|c|c|c|}
\hline \multirow[b]{2}{*}{ Parameterization of age controls } & \multicolumn{2}{|c|}{$\begin{array}{c}\text { Dependent variable: } \\
\text { Enrolled in savings plan }\end{array}$} & \multicolumn{2}{|c|}{$\begin{array}{l}\text { Dependent variable: } \\
\text { Before-tax contribution } \\
\text { rate change }\end{array}$} \\
\hline & $0 \%$ default & $6 \%$ default & $0 \%$ default & $6 \%$ default \\
\hline $\begin{array}{l}\text { Age spline with knot points every } 5 \\
\text { years (Baseline from Table VII) }\end{array}$ & $\begin{array}{l}-1.760 * * \\
(0.731)\end{array}$ & $\begin{array}{r}1.083^{*} \\
(0.559)\end{array}$ & $\begin{array}{c}-10.663 * * \\
(4.613)\end{array}$ & $\begin{array}{r}5.558^{*} \\
(2.935)\end{array}$ \\
\hline $\begin{array}{l}\text { Age spline with knot points every } \\
2.5 \text { years }\end{array}$ & $\begin{array}{l}-1.736^{* *} \\
(0.734)\end{array}$ & $\begin{array}{l}1.342 * * \\
(0.662)\end{array}$ & $\begin{array}{l}-10.520 * * \\
(4.636)\end{array}$ & $\begin{array}{l}6.760 * * \\
(3.285)\end{array}$ \\
\hline $\begin{array}{l}\text { Dummies for target date retirement } \\
\text { fund offered }\end{array}$ & $\begin{array}{l}-1.931 * * * \\
(0.723)\end{array}$ & $\begin{array}{l}0.990 * \\
(0.574)\end{array}$ & $\begin{array}{l}-11.665^{* *} \\
(4.558)\end{array}$ & $\begin{array}{l}5.797^{*} \\
(3.396)\end{array}$ \\
\hline $\begin{array}{l}\text { Controls for years from age group } \\
\text { mean (linear and squared) }\end{array}$ & $\begin{array}{l}-2.041 * * \\
(0.797)\end{array}$ & $\begin{array}{c}0.890 \\
(0.596)\end{array}$ & $\begin{array}{l}-12.220 * * \\
(4.994)\end{array}$ & $\begin{array}{c}5.111 \\
(3.517)\end{array}$ \\
\hline $\begin{array}{l}\text { Controls for percentile within age } \\
\text { group (linear and squared) }\end{array}$ & $\begin{array}{l}-1.757 * * \\
(0.748)\end{array}$ & $\begin{array}{l}1.180 * \\
(0.657)\end{array}$ & $\begin{array}{l}-10.438 * * \\
(4.673)\end{array}$ & $\begin{array}{l}6.519 * \\
(3.798)\end{array}$ \\
\hline Sample size & $N=687$ & $N=264$ & $N=687$ & $N=264$ \\
\hline
\end{tabular}


Table X: Effect of Receiving Peer Information in Easy Escalation: Mean Comparisons This table shows the average responses of employees who received Easy Escalation mailings, reported separately by contribution rate default and treatment condition, and the differences in these average responses across treatment conditions. The responses of interest are increasing one's before-tax contribution rate between August 4, 2008 and September 8, 2008 and the before-tax contribution rate change during the same time period. Easy Escalation recipients in the peer information treatments were shown the fraction of plan participants in their five-year or ten-year age bracket with before-tax contribution rates of at least $6 \%$. The first two columns display standard errors from tests of proportions in parentheses, with the standard errors in the last row calculated under the null hypothesis that the two proportions are equal. The last two columns display standard errors robust to heteroskedasticity in parentheses. *, **, and *** in the last row indicate statistical significance at the $10 \%, 5 \%$, and $1 \%$ levels, respectively.

\begin{tabular}{|c|c|c|c|c|}
\hline & \multicolumn{2}{|c|}{$\begin{array}{c}\text { Fraction who increased } \\
\text { before-tax contribution rate }\end{array}$} & \multicolumn{2}{|c|}{$\begin{array}{c}\text { Average before-tax } \\
\text { contribution rate change }\end{array}$} \\
\hline & $0 \%$ default & $6 \%$ default & $0 \%$ default & $6 \%$ default \\
\hline (1) No peer info & $\begin{array}{l}10.6 \% \\
(2.0)\end{array}$ & $\begin{array}{l}8.2 \% \\
(0.9)\end{array}$ & $\begin{array}{l}0.33 \% \\
(0.08)\end{array}$ & $\begin{array}{l}0.26 \% \\
(0.04)\end{array}$ \\
\hline (2) 5-year age bracket info & $\begin{array}{l}9.8 \% \\
(1.9)\end{array}$ & $\begin{array}{l}7.8 \% \\
(0.9)\end{array}$ & $\begin{array}{l}0.30 \% \\
(0.07)\end{array}$ & $\begin{array}{l}0.29 \% \\
(0.05)\end{array}$ \\
\hline (3) 10-year age bracket info & $\begin{array}{l}11.3 \% \\
(2.0)\end{array}$ & $\begin{array}{l}8.8 \% \\
(0.9)\end{array}$ & $\begin{array}{l}0.38 \% \\
(0.09)\end{array}$ & $\begin{array}{l}0.40 \% \\
(0.07)\end{array}$ \\
\hline (4) Combined 5-year and 10-year & $\begin{array}{l}10.6 \% \\
(1.4)\end{array}$ & $\begin{array}{l}8.3 \% \\
(0.6)\end{array}$ & $\begin{array}{c}0.34 \% \\
(0.06)\end{array}$ & $\begin{array}{l}0.35 \% \\
(0.05)\end{array}$ \\
\hline Difference: $(4)-(1)$ & $\begin{array}{l}-0.1 \% \\
(2.4)\end{array}$ & $\begin{array}{c}0.1 \% \\
(1.1)\end{array}$ & $\begin{array}{l}0.01 \% \\
(0.10)\end{array}$ & $\begin{array}{l}0.08 \% \\
(0.06)\end{array}$ \\
\hline
\end{tabular}


Table XI: Effect of Receiving Peer Information in Easy Escalation: Regression Analysis This table reports the results of ordinary least-squares regressions where the dependent variable is either a dummy for increasing one's before-tax contribution rate between August 4, 2008 and September 8, 2008 or the before-tax contribution rate change during the same time period. The sample is Easy Escalation recipients with a $0 \%$ contribution rate default (columns 1 and 3 ) or a $6 \%$ contribution rate default (columns 2 and 4). The linear spline in age has knot points at 22.5, 27.5, 32.5, ..., and 67.5. Before-tax contribution rates as of July 14, 2008 are controlled for using a full set of contribution rate dummies. All regressions include a constant. Standard errors robust to heteroskedasticity are in parentheses. $*, * *$, and $* * *$ indicate statistical significance at the $10 \%, 5 \%$, and $1 \%$ levels, respectively.

\begin{tabular}{|c|c|c|c|c|}
\hline \multirow[b]{3}{*}{$\begin{array}{l}\text { Received peer } \\
\text { info dummy }\end{array}$} & \multicolumn{2}{|c|}{$\begin{array}{c}\text { Dependent variable: } \\
\text { Increased before-tax contribution rate }\end{array}$} & \multicolumn{2}{|c|}{$\begin{array}{l}\text { Dependent variable: } \\
\text { Before-tax contribution rate change }\end{array}$} \\
\hline & $0 \%$ default & $6 \%$ default & $0 \%$ default & $6 \%$ default \\
\hline & $\begin{array}{l}-0.004 \\
(0.025)\end{array}$ & $\begin{array}{c}0.001 \\
(0.011)\end{array}$ & $\begin{array}{l}-0.008 \\
(0.101)\end{array}$ & $\begin{array}{c}0.072 \\
(0.057)\end{array}$ \\
\hline Male dummy & $\begin{array}{l}-0.052 * * \\
(0.026)\end{array}$ & $\begin{array}{c}0.002 \\
(0.011)\end{array}$ & $\begin{array}{l}-0.147 \\
(0.105)\end{array}$ & $\begin{array}{c}0.024 \\
(0.047)\end{array}$ \\
\hline $\log ($ Tenure $)$ & $\begin{array}{l}-0.003 \\
(0.014)\end{array}$ & $\begin{array}{c}0.002 \\
(0.005)\end{array}$ & $\begin{array}{l}-0.047 \\
(0.056)\end{array}$ & $\begin{array}{c}0.030 \\
(0.023)\end{array}$ \\
\hline $\log$ (Salary) & $\begin{array}{c}0.064 * \\
(0.038)\end{array}$ & $\begin{array}{l}0.056^{* * *} \\
(0.014)\end{array}$ & $\begin{array}{l}0.308 * * \\
(0.147)\end{array}$ & $\begin{array}{l}0.406^{* * *} \\
(0.115)\end{array}$ \\
\hline Age spline & Yes & Yes & Yes & Yes \\
\hline $\begin{array}{l}\text { Contribution rate } \\
\text { dummies }\end{array}$ & Yes & Yes & Yes & Yes \\
\hline$R^{2}$ & 0.029 & 0.024 & 0.041 & 0.018 \\
\hline Sample size & $N=746$ & $N=2,753$ & $N=746$ & $N=2,753$ \\
\hline
\end{tabular}


Table XII: Effect of the Peer Information Value Received in Easy Escalation

This table reports the results of ordinary least-squares regressions where the dependent variable is either a dummy for increasing one's before-tax contribution rate between August 4, 2008 and September 8, 2008 or the before-tax contribution rate change during the same time period. The sample is Easy Escalation recipients who were given peer information and have a $0 \%$ contribution rate default (columns 1 and 3 ) or a $6 \%$ contribution rate default (columns 2 and 4 ). The peer information value was the fraction of savings plan participants in the recipient's fiveyear or ten-year age bracket with before-tax contribution rates of at least $6 \%$. The linear spline in age has knot points at 22.5, 27.5, 32.5, .., and 67.5. Before-tax contribution rates as of July 14, 2008 are controlled for using a full set of contribution rate dummies. All regressions include a constant. Standard errors robust to heteroskedasticity are in parentheses. $*, * *$, and $* * *$ indicate statistical significance at the $10 \%, 5 \%$, and $1 \%$ levels, respectively.

\begin{tabular}{|c|c|c|c|c|}
\hline \multirow{3}{*}{ Peer info value } & \multicolumn{2}{|c|}{$\begin{array}{c}\text { Dependent variable: } \\
\text { Increased before-tax contribution rate }\end{array}$} & \multicolumn{2}{|c|}{$\begin{array}{l}\text { Dependent variable: } \\
\text { Before-tax contribution rate change }\end{array}$} \\
\hline & $0 \%$ default & $6 \%$ default & $0 \%$ default & $6 \%$ default \\
\hline & $\begin{array}{c}2.309 \\
(1.901)\end{array}$ & $\begin{array}{c}0.494 \\
(0.813)\end{array}$ & $\begin{array}{l}11.108 \\
(7.085)\end{array}$ & $\begin{array}{r}7.414^{*} \\
(4.179)\end{array}$ \\
\hline Male dummy & $\begin{array}{l}-0.035 \\
(0.031)\end{array}$ & $\begin{array}{l}-0.002 \\
(0.014)\end{array}$ & $\begin{array}{l}-0.050 \\
(0.124)\end{array}$ & $\begin{array}{c}0.014 \\
(0.062)\end{array}$ \\
\hline $\log ($ Tenure $)$ & $\begin{array}{l}0.000 \\
(0.017)\end{array}$ & $\begin{array}{l}-0.002 \\
(0.006)\end{array}$ & $\begin{array}{l}-0.063 \\
(0.069)\end{array}$ & $\begin{array}{c}0.019 \\
(0.032)\end{array}$ \\
\hline $\log ($ Salary $)$ & $\begin{array}{c}0.069 \\
(0.055)\end{array}$ & $\begin{array}{l}0.056^{* * *} \\
(0.017)\end{array}$ & $\begin{array}{r}0.371^{*} \\
(0.215)\end{array}$ & $\begin{array}{l}0.487 * * * \\
(0.166)\end{array}$ \\
\hline Age spline & Yes & Yes & Yes & Yes \\
\hline $\begin{array}{l}\text { Contribution rate } \\
\text { dummies }\end{array}$ & Yes & Yes & Yes & Yes \\
\hline$R^{2}$ & 0.041 & 0.020 & 0.064 & 0.021 \\
\hline Sample size & $N=511$ & $N=1,822$ & $N=511$ & $N=1,822$ \\
\hline
\end{tabular}


Table XIII: Effect of Receiving Peer Information in Quick Enrollment Among Employees with a $0 \%$ Contribution Default: Interaction with Relative Salary Within Firm and State This table reports the results of ordinary least-squares regressions where the dependent variable is either a dummy for enrolling in the savings plan between August 4, 2008 and September 8, 2008 or the before-tax contribution rate change during the same time period. The sample in the left two columns is Quick Enrollment recipients who have a $0 \%$ contribution rate default. In the right two columns, this sample is further restricted to employees who received peer information. "Salary below median in firm and state" is a dummy for having a salary below the median salary among all active employees at the firm in the same state, including those not in the experiment. "Peer info value" is the plan participation rate of coworkers in the recipient's five-year or tenyear age bracket. The linear spline in recipient age has knot points at 22.5, 27.5, 32.5, .., and 67.5. In the right two columns, all components of the age spline are also interacted with the salary below median dummy. All regressions include a constant. Standard errors robust to heteroskedasticity are in parentheses. $*, * *$, and *** indicate statistical significance at the $10 \%$, $5 \%$, and $1 \%$ levels, respectively.

\begin{tabular}{|c|c|c|c|c|}
\hline & $\begin{array}{l}\text { Enrolled } \\
\text { in plan }\end{array}$ & $\begin{array}{l}\text { Contribution } \\
\text { rate change }\end{array}$ & $\begin{array}{l}\text { Enrolled } \\
\text { in plan }\end{array}$ & $\begin{array}{l}\text { Contribution } \\
\text { rate change }\end{array}$ \\
\hline $\begin{array}{l}\text { Received peer info } \\
\text { dummy }\end{array}$ & $\begin{array}{c}0.007 \\
(0.018)\end{array}$ & $\begin{array}{c}0.042 \\
(0.105)\end{array}$ & & \\
\hline $\begin{array}{l}\text { Salary below } \\
\text { median in firm and } \\
\text { state } \times \text { peer info }\end{array}$ & $\begin{array}{l}-0.052 * \\
(0.028)\end{array}$ & $\begin{array}{l}-0.291 * \\
(0.167)\end{array}$ & & \\
\hline Peer info value & & & $\begin{array}{c}0.984 \\
(0.847)\end{array}$ & $\begin{array}{c}5.988 \\
(5.112)\end{array}$ \\
\hline $\begin{array}{l}\text { Salary below } \\
\text { median in firm and } \\
\text { state } \times \text { peer value }\end{array}$ & & & $\begin{array}{c}-2.844 * * \\
(1.126)\end{array}$ & $\begin{array}{c}-17.254 * * \\
(7.025)\end{array}$ \\
\hline $\begin{array}{l}\text { Salary below } \\
\text { median in firm and } \\
\text { state }\end{array}$ & $\begin{array}{c}0.079 * * * \\
(0.022)\end{array}$ & $\begin{array}{c}0.457 * * * \\
(0.132)\end{array}$ & $\begin{array}{l}3.923 * * \\
(1.642)\end{array}$ & $\begin{array}{c}20.611 * * \\
(9.140)\end{array}$ \\
\hline Male dummy & $\begin{array}{l}-0.011 \\
(0.020)\end{array}$ & $\begin{array}{l}-0.035 \\
(0.118)\end{array}$ & $\begin{array}{c}0.014 \\
(0.023)\end{array}$ & $\begin{array}{c}0.108 \\
(0.139)\end{array}$ \\
\hline $\log ($ Tenure $)$ & $\begin{array}{c}-0.024 * * * \\
(0.008)\end{array}$ & $\begin{array}{c}-0.142 * * * \\
(0.047)\end{array}$ & $\begin{array}{l}-0.009 \\
(0.009)\end{array}$ & $\begin{array}{l}-0.055 \\
(0.054)\end{array}$ \\
\hline $\log ($ Salary $)$ & $\begin{array}{c}0.021 \\
(0.023)\end{array}$ & $\begin{array}{c}0.100 \\
(0.137)\end{array}$ & $\begin{array}{l}-0.017 \\
(0.029)\end{array}$ & $\begin{array}{l}-0.108 \\
(0.178)\end{array}$ \\
\hline Age spline & Yes & Yes & Yes & Yes \\
\hline $\begin{array}{l}\text { Salary below med } \\
\times \text { age spline }\end{array}$ & No & No & Yes & Yes \\
\hline$R^{2}$ & 0.035 & 0.031 & 0.041 & 0.040 \\
\hline Sample size & $N=1,024$ & $N=1,024$ & $N=687$ & $N=687$ \\
\hline
\end{tabular}


Table XIV: Effect of Receiving Peer Information in Quick Enrollment Among Employees with a $0 \%$ Contribution Default: Interaction with Salary Relative to Firm-Wide Median This table reports the results of ordinary least-squares regressions where the dependent variable is either a dummy for enrolling in the savings plan between August 4, 2008 and September 8, 2008 or the before-tax contribution rate change during the same time period. The sample in the left two columns is Quick Enrollment recipients who have a $0 \%$ contribution rate default. In the right two columns, this sample is further restricted to employees who received peer information. "Salary below firm median" is a dummy for having a salary below the median salary among all active employees in the firm, including those not in the experiment. "Peer info value" is the plan participation rate of coworkers in the recipient's five-year or ten-year age bracket. The linear spline in recipient age has knot points at $22.5,27.5,32.5, \ldots$, and 67.5 . In the right two columns, all components of the age spline are also interacted with the salary below firm median dummy. All regressions include a constant. Standard errors robust to heteroskedasticity are in parentheses. $* * *$, and $* * *$ indicate statistical significance at the $10 \%, 5 \%$, and $1 \%$ levels, respectively.

\begin{tabular}{|c|c|c|c|c|}
\hline & $\begin{array}{l}\text { Enrolled } \\
\text { in plan }\end{array}$ & $\begin{array}{l}\text { Contribution } \\
\text { rate change }\end{array}$ & $\begin{array}{l}\text { Enrolled } \\
\text { in plan }\end{array}$ & $\begin{array}{l}\text { Contribution } \\
\text { rate change }\end{array}$ \\
\hline $\begin{array}{l}\text { Received peer info } \\
\text { dummy }\end{array}$ & $\begin{array}{l}-0.025 \\
(0.032)\end{array}$ & $\begin{array}{l}-0.149 \\
(0.192)\end{array}$ & & \\
\hline $\begin{array}{l}\text { Salary below firm } \\
\text { median } \times \text { peer info }\end{array}$ & $\begin{array}{l}-0.019 \\
(0.039)\end{array}$ & $\begin{array}{l}-0.089 \\
(0.230)\end{array}$ & & \\
\hline Peer info value & & & $\begin{array}{l}-2.189 \\
(1.989)\end{array}$ & $\begin{array}{l}-13.142 \\
(11.911)\end{array}$ \\
\hline $\begin{array}{l}\text { Salary below firm } \\
\text { median } \times \text { peer value }\end{array}$ & & & $\begin{array}{c}0.458 \\
(2.129)\end{array}$ & $\begin{array}{c}2.647 \\
(12.823)\end{array}$ \\
\hline $\begin{array}{l}\text { Salary below firm } \\
\text { median }\end{array}$ & $\begin{array}{c}0.051 \\
(0.039)\end{array}$ & $\begin{array}{c}0.281 \\
(0.232)\end{array}$ & $\begin{array}{c}0.654 \\
(1.914)\end{array}$ & $\begin{array}{c}0.776 \\
(10.943)\end{array}$ \\
\hline Male dummy & $\begin{array}{l}-0.013 \\
(0.020)\end{array}$ & $\begin{array}{l}-0.045 \\
(0.117)\end{array}$ & $\begin{array}{c}0.013 \\
(0.022)\end{array}$ & $\begin{array}{c}0.100 \\
(0.137)\end{array}$ \\
\hline $\log$ (Tenure) & $\begin{array}{c}-0.024 * * * \\
(0.008)\end{array}$ & $\begin{array}{l}-0.144 * * * \\
(0.047)\end{array}$ & $\begin{array}{l}-0.009 \\
(0.009)\end{array}$ & $\begin{array}{l}-0.054 \\
(0.054)\end{array}$ \\
\hline $\log$ (Salary) & $\begin{array}{c}0.028 \\
(0.025)\end{array}$ & $\begin{array}{c}0.141 \\
(0.153)\end{array}$ & $\begin{array}{l}-0.010 \\
(0.033)\end{array}$ & $\begin{array}{l}-0.069 \\
(0.206)\end{array}$ \\
\hline Age spline & Yes & Yes & Yes & Yes \\
\hline $\begin{array}{l}\text { Salary below firm } \\
\text { med. } \times \text { age spline }\end{array}$ & No & No & Yes & Yes \\
\hline$R^{2}$ & 0.034 & 0.030 & 0.043 & 0.042 \\
\hline Sample size & $N=1,024$ & $N=1,024$ & $N=687$ & $N=687$ \\
\hline
\end{tabular}




\section{Table XV: Effect of Receiving Peer Information in Easy Escalation: Interaction with Before-Tax Contribution Rate Prior to the Experiment}

This table reports the results of ordinary least-squares regressions where the dependent variable is either a dummy for increasing one's before-tax contribution rate between August 4, 2008 and September 8, 2008 or the before-tax contribution rate change during the same time period. The sample is Easy Escalation recipients with a $0 \%$ contribution rate default (columns 1 and 3 ) or a $6 \%$ contribution rate default (columns 2 and 4). Before-tax contribution rates as of July 14, 2008 are controlled for using a full set of contribution rate dummies. The regressions also include the interaction between the dummy for receiving peer information and a dummy for having a beforetax contribution rate of $0 \%, 1 \%$, or $2 \%$ (as opposed to $3 \%, 4 \%$, or $5 \%$ ). The linear spline in age has knot points at 22.5, 27.5, 32.5, ..., and 67.5. All regressions include a constant. Standard errors robust to heteroskedasticity are in parentheses. $*, * *$, and $* * *$ indicate statistical significance at the $10 \%, 5 \%$, and $1 \%$ levels, respectively.

\begin{tabular}{|c|c|c|c|c|}
\hline \multirow[b]{3}{*}{$\begin{array}{l}\text { Received peer } \\
\text { info dummy }\end{array}$} & \multicolumn{2}{|c|}{$\begin{array}{c}\text { Dependent variable: } \\
\text { Increased before-tax contribution rate }\end{array}$} & \multicolumn{2}{|c|}{$\begin{array}{l}\text { Dependent variable: } \\
\text { Before-tax contribution rate change }\end{array}$} \\
\hline & $0 \%$ default & $6 \%$ default & $0 \%$ default & $6 \%$ default \\
\hline & $\begin{array}{c}0.038 \\
(0.034)\end{array}$ & $\begin{array}{l}-0.019 \\
(0.021)\end{array}$ & $\begin{array}{c}0.175^{*} \\
(0.090)\end{array}$ & $\begin{array}{l}-0.041 \\
(0.063)\end{array}$ \\
\hline $\begin{array}{l}\text { Cont. rate } 0 \% \text { to } \\
2 \% \times \text { peer info }\end{array}$ & $\begin{array}{l}-0.087 * \\
(0.049)\end{array}$ & $\begin{array}{c}0.032 \\
(0.024)\end{array}$ & $\begin{array}{l}-0.378 * \\
(0.200)\end{array}$ & $\begin{array}{c}0.184^{*} \\
(0.107)\end{array}$ \\
\hline Male dummy & $\begin{array}{l}-0.052 * * \\
(0.026)\end{array}$ & $\begin{array}{c}0.002 \\
(0.011)\end{array}$ & $\begin{array}{l}-0.147 \\
(0.105)\end{array}$ & $\begin{array}{c}0.024 \\
(0.047)\end{array}$ \\
\hline $\log$ (Tenure) & $\begin{array}{l}-0.003 \\
(0.014)\end{array}$ & $\begin{array}{c}0.001 \\
(0.005)\end{array}$ & $\begin{array}{l}-0.048 \\
(0.057)\end{array}$ & $\begin{array}{c}0.029 \\
(0.023)\end{array}$ \\
\hline $\log$ (Salary) & $\begin{array}{c}0.059 \\
(0.038)\end{array}$ & $\begin{array}{l}0.056^{* * *} \\
(0.014)\end{array}$ & $\begin{array}{l}0.286^{*} \\
(0.147)\end{array}$ & $\begin{array}{l}0.406^{* * *} \\
(0.115)\end{array}$ \\
\hline Age spline & Yes & Yes & Yes & Yes \\
\hline $\begin{array}{l}\text { Contribution rate } \\
\text { dummies }\end{array}$ & Yes & Yes & Yes & Yes \\
\hline$R^{2}$ & 0.033 & 0.025 & 0.045 & 0.018 \\
\hline Sample size & $N=746$ & $N=2,753$ & $N=746$ & $N=2,753$ \\
\hline
\end{tabular}

